MINYAK BUMI DI INDONESIA

OLEH :

IR. SYAMSUL BAKHRI, S.T, M.T, IPM

Dosen, Program Studi Teknik Kimia, Fakultas Teknologi Industri, Universitas Muslim Indonesia, Jl. Urip Sumahrdjo Km.5, Kota Makassar.

1 


\section{B A B I}

\section{P E N D A H U L U A N}

Minyak bumi telah membawa kemajuan yang pesat di dunia, sehingga jika seandainya minyak bumi tidak ada, maka dunia tidak akan semaju sekarang ini. Dimana-mana dalam kehidupan sehari-hari, hampir selalu dijumpai produk-produk yang berasal dari minyak bumi, baik produk yang berasal dari kilang minyak atau produk petrokimia.

Walaupun minyak bumi ini telah lama sekali dikenal orang, namun industri minyak bumi baru muncul setelah Drake berhasil mengeluarkan minyak bumi dari dalam bumi dengan bor tumbuknya pada tahun 1859 di Titusville, Pennsylvania, Amerika Serikat.

Bukti bahwa minyak bumi telah lama sekali dikenal orang, yaitu dengan ditemukannya aspal sebagai bahan perekat pada bangunan-bangunan kuno yang didirikan lebih dari 6,000 tahun yang lalu di tepi sungai Euphrat, Irak. Penggalian kota-kota kuno seperti Kish, Ur, Babilon, dan Niniveh menunjukkan bahwa aspal telah digunakan orang bahan yang tahan terhadap air untuk bak mandi, kapal, dan juga sebagai bahan perekat barang pecah dan sebagai cat. Bahkan, di Mesir lebih dari 1,000 tahun SM, aspal telah digunakan untuk pembuatan mumi dengan cara melapisi kain pembungkus mayat yang telah dibalsam dengan aspal.

Peradaban China yang berkembang di sungai Kuning, juga telah mengenal dan menggunakan minyak bumi yang diperoleh pada pengeboran sumur dengan maksud terutama untuk menghasilkan garam. Sekurang-kurangnya 2,000 tahun yang lampau, minyak dan gas bumi telah digunakan di China untuk pemanasan dan penerangan.

Setelah Drake berhasil mengeluarkan minyak bumi dari perut bumi dengan jalan mengebornya, maka kemudian banyak orang mulai berlomba-lomba berspekulasi untuk mendapatkan minyak bumi dengan jalan melakukan pengeboran di mana-mana. 


\section{ASAL USUL MINYAK BUMI}

Minyak bumi berasal dari formasi batuan yang berumur antara $10-400$ juta tahun. Pembentukan minyak bumi berkaitan dengan pengembangan batuan sedimen berbutir halus, yang mengendap di laut atau di dekat laut, dan merupakan produk dari binatang dan tumbuh-tumbuhan yang hidup di laut.

Pada tahun 1866, Benthelot mengajukan teori bahwa minyak bumi berasal dari reaksi antara karbid dengan air yang menghasilkan asetilen, yang selanjutnya karena suhu dan tekanan yang tinggi asetilen berubah menjadi minyak bumi. Berthelot menganggap bahwa karbid terjadi karena reaksi antara karbonat dengan logam alkali.

\section{$\mathrm{CaCO}_{3} \rightarrow \mathrm{CaC}_{2} \rightarrow \mathrm{HC}=\mathrm{CH} \rightarrow$ Minyak Bumi}

Teori anorganik yang lain, di mana asetilen juga merupakan bahan dasar, diajukan oleh Mendelejeff. Menurutnya asetilen terjadi karena reaksi antara logam karbid dengan asam.

Teori organik mengenai terjadinya minyak bumi diajukan oleh Engler pada tahun 1911 yang mengatakan bahwa minyak bumi terjadi dari bahan organik melalui tiga tahap. Tahap Pertama, deposit binatang dan tumbuh-tumbuhan berkumpul pada dasar laut, yang selanjutya akan terurai oleh bakteri. Karbohidrat dan Protein yang diubah menjadi bahan yang dapat larut dalam air atau menjadi gas, akan terbawa oleh aliran air atau aliran udara. Sedangkan lemak, dan bahan lain yang stabil (rosin, kolesterol, dan lainlain) akan tetap tinggal. Tahap Kedua, suhu dan tekanan yang tinggi akan mengakibatkan terbentuknya karbon dioksida dari senyawa-senyawa yang mengandung gugus karboksil, dan air akan terbentuk dari asam hidroksi dan alcohol dan akan menghasilkan residu bitumen. Panas dan tekanan selanjutnya dapat menyebabkan terjadinya rengkahan, yang menghasilkan cairan yang mempunyai kandungan olefin yang tinggi, yang disebut protopetroleum. Pada Tahap Ketiga, komponen tidak jenuh yang ada dalam protopetroleum akan berpolimerisasi karena pengaruh katalis, sehingga poliolefin akan berubah menjadi senyawa hidrokarbon naften dan paraffin. Senyawa karbon aromatis dianggap terbentuk secara langsung pada proses rengkahan atau siklisasi melalui reaksi kondensasi. Keberatan dari teori ini antara lain adalah bahwa hasil akhir yang diperoleh pada percobaan berbeda dengan komposisi minak bumi yang terutama terdiri dari senyawa hidrokarbon paraffin, naften, dan aromat.

\section{SEJARAH MINYAK BUMI DI INDONESIA}


Pada abad ke VIII, orang-orang Indonesia yang tinggal di sekitar selat Sumatera telah mengenal minyak bumi dan telah memanfaatkannya sebagai alat pembakar dalam pertempuran di laut. Pada abad ke XVI, armada laut Aceh dapat mengalahkan armada laut Portugis yang dipimpin oleh Alfonso D'albuquergue dengan menggunakan bola api yang dilemparkan dari kapal perang Aceh. Pada waktu itu minyak yang digunakan adalah minyak bumi yang merembes keluar ke permukaan bumi.

Pada zaman penjajahan Belanda, sejak tahun 1871 orang-orang Belanda telah berusaha untuk mendapatkan minyak bumi di Indonesia dengan melakukan pengeboran di daerahdaerah yang ada rembesan minyak bumi yang selanjutnya diolah menjadi minyak lampu. Pada tanggal 15 Juni 1885, seorang pemimpin perkebunan Belanda bernama Aeilco Janszoon Zylker berhasil melakukan pengeboran yang pertama di Telaga Tunggal dekat Pangkalan Brandan di Sumatera Utara pada kedalaman kira-kira 400 kaki. Sejak penemuan ini, pencarian minyak bumi terus berlanjut yang saat hampir bersamaan telah pula ditemukan minyak bumi di tempat lain di Indonesia, seperti di desa Ledok Jawa Tengah, desa Minyak Hitam di daerah Muara Enim Palembang, dan Riam Kiwa dekat Sangasanga di Kalimantan Timur.

Dengan ditemukannya minyak bumi di Indonesia, mengakibatkan tumbuhnya perusahaan minyak asing, di mana pada akhir abad XIX tidak kurang dari 18 perusahaan asing yang secara aktif mencari sumber-sumber (Eksplorasi) minyak di Indonesia. Pada tahun 1902, Royal Dutch Company yaitu perusahaan yang mengambil alih konsesi Zylker, dapat mengalahkan perusahaan-perusahaan yang ada pada waktu itu. Tahun 1907, Royal Dutch Company bergabung dengan Shell Transport and Trading Company, dan perusahaan yang beroperasi dari kelompok Royal Dutch dan Shell di Indonesia adalah Bataafshe Petroleum Maatschppij (B.P.M), dan ini merupakan satu-satunya perusahaan yang beroperasi di Indonesia sampai tahun 1911. Pada tahun 1912, Standard Vacum Oil Company (STANVAC), suatu anak perusahaan Standard Oil (New Jersey) dan Vacum Oil Company mulai beroperasi di Indonesia dan mengerjakan lapangan-lapangan minyak di Talang Akar dan Pendopo Sumatera Selatan. Untuk menghadapi saingan dari Standard Oil ini, maka pada tahun 1930 oleh pemerintah colonial Belanda dan B.P.M dibentuklah suatu perusahaan konsorsium, yaitu N.V. Nederlandsche Indische Aardolie Maatschappij (N.I.A.M). Pada tahun 1935, CALTEX yaitu sebuah anak perusahaan Standard Oil of California and Texas Company mulai beroperasi di Indonesia, di mana ladang produksinya terletak di Minas dan Duri di daerah Daratan Riau. Pada tahun 1935, dibentuk perusahaan minyak bernama Nederlandsche Nieuw Guinea Petroleum Maatschappij (N.N.G.P.M) untuk mengeksploitasi Irian Jaya bagian barat, yang sahamnya milik Royal Dutch-Shell, Stanvac, dan Caltex. Terdapat 6 Lokasi Kilang minyak yang ada sebelum perang dunia II, yaitu Plaju (B.P.M), 
Sungai Gerong (STANVAC), Balikpapan (B.P.M), Cepu (B.P.M), Wonokromo (B.P.M), dan Pangkalan Brandan (B.P.M).

Dengan pecahnya perang dunia II, karena serbuan tentara Jepang ke Indonesia, maka karena sistem politik bumi hangus pemerintah Hindia Belanda, sebagian besar instalasiinstalasi kilang minyak hancur, terutama di Pangkalan Brandan.

Setelah Kemerdekaan Republik Indonesia 17 Agustus 1945, satu-satunya ladang minyak yang dikuasai oleh Pejuang Kemerdekaan adalah ladang minyak sekitar Pangkalan Brandan dan daerah Aceh yang merupakan bekas milik Shell-B.P.M, yang selanjutnya merupakan perusahaan minyak Indonesia yang pertama dan diberi nama Perusahaan Tambang Minyak Negara Republik Indonesia (P.T.M.N.R.I). Pada tahun 1945, B.P.M berhasil meneruskan produksi minyak mentahnya di Tarakan, dan pada tahun 1946, kilang Plaju dan Sungai Gerong masing-masing dikembalikan kepada B.P.M dan STANVAC untuk rekonstruksi. Di jawa tengah, B.P.M tidak berhasil memperoleh kembali ladang minyak Kawenga, Ledok, dan Cepu, karena telah dikuasai oleh koperasi buruh minyak yang kemudian menjadi perusahaan negara PERMIGAN.

Setelah perjuangan fisik tahun 1950, P.T.M.N.R.I belum menunjukkan usaha-usaha pembangunannya, maka pada bulan april 1954, P.T.M.N.R.I diubah menjadi Tambang Minyak Sumatera Utara (T.M.S.U). Tindakan ini ternyata juga tidak mendatangkan manfaat, sehingga pada tanggal 10 Desember 1957 T.M.S.U diubah menjadi P.T. Perusahaan Tambang Minyak Indonesia (P.T. PERMINA). Setelah kira-kira tiga setengah tahun, tepatnya tanggal 1 Juli 1961 statusnya diubah menjadi Perusahaan Negara Pertambangan Minyak Nasional (P.N. PERMINA).

Dengan penyerahan kedaulatan oleh pemerintah kolonial Belanda kepada Republik Indonesia, maka pada tanggal 1 Januari 1959 status N.V. N.I.A.M diubah menjadi P.T. Pertambangan Minyak Indonesia (P.T. PERMINDO). Karena jangka waktu berdirinya N.V.N.I.A.M hanya sampai tanggal 31 Desember 1960, maka pada bulan Februari 1961 didirikan Perusahaan Negara Pertambangan Minyak Indonesia

(P.N. PERTAMIN) dan untuk melancarkan usaha tersebut, P.N. PERTAMIN ditunjuk sebagai satu-satunya distributor minyak di dalam negeri dan bertanggungjawab atas penyediaan minyak bagi Angkatan Bersenjata Republik Indonesia (ABRI). Akhirnya untuk mempertegas struktur dan prosedur kerja demi memperlancar usaha peningkatan produksi minyak dan gas bumi, maka pada tanggal 20 Agustus 1968 P.N. PERMINA dan P.N. PERTAMIN dilebur menjadi perusahaan Negara Minyak dan Gas Bumi Nasional (P.N. PERTAMINA).

\section{KILANG MINYAK DI INDONESIA}


Kilang minyak di Indonesia tersebar di beberapa tempat di pulau Jawa, Sumatera, Kalimantan, dan Irian Jaya. Sebagian dari kilang minyak di tempat tersebut, didirikan pada zaman penjajahan Belanda, yaitu kilang minyak Pangkalan Brandan, Sungai Gerong, Plaju, Cepu, Wonokromo, dan Balikpapan, dan sebagian lainnya didirikan setelah Indonesia Merdeka yaitu kilang minyak di Sungai Pakning, Dumai, Cilacap, Balongan, dan Kasim. Kilang Wonokromo, sekarang sudah tidak beroperasi lagi.

Berikut, Daftar Kilang Minyak di Indonesia beserta Kapasitasnya.

Tabel 1 - 1. Kilang Minyak dan Kapasitasnya di Indonesia

\begin{tabular}{|lc|}
\hline KILANG MINYAK & KAPASITAS, Ribu Barel / Hari \\
\hline Musi & 132,5 \\
\hline Dumai & 120 \\
\hline Sungai Pakning & 50 \\
\hline Pangkalan Brandan & 5 \\
\hline Cilacap & 300 \\
\hline Balikpapan & 253,6 \\
\hline Cepu & 4 \\
\hline Balongan (Exor I) & 125 \\
\hline Kasim & 4 \\
\hline T O T A L & $\mathbf{9 9 4 , \mathbf { 1 }}$ \\
\hline
\end{tabular}




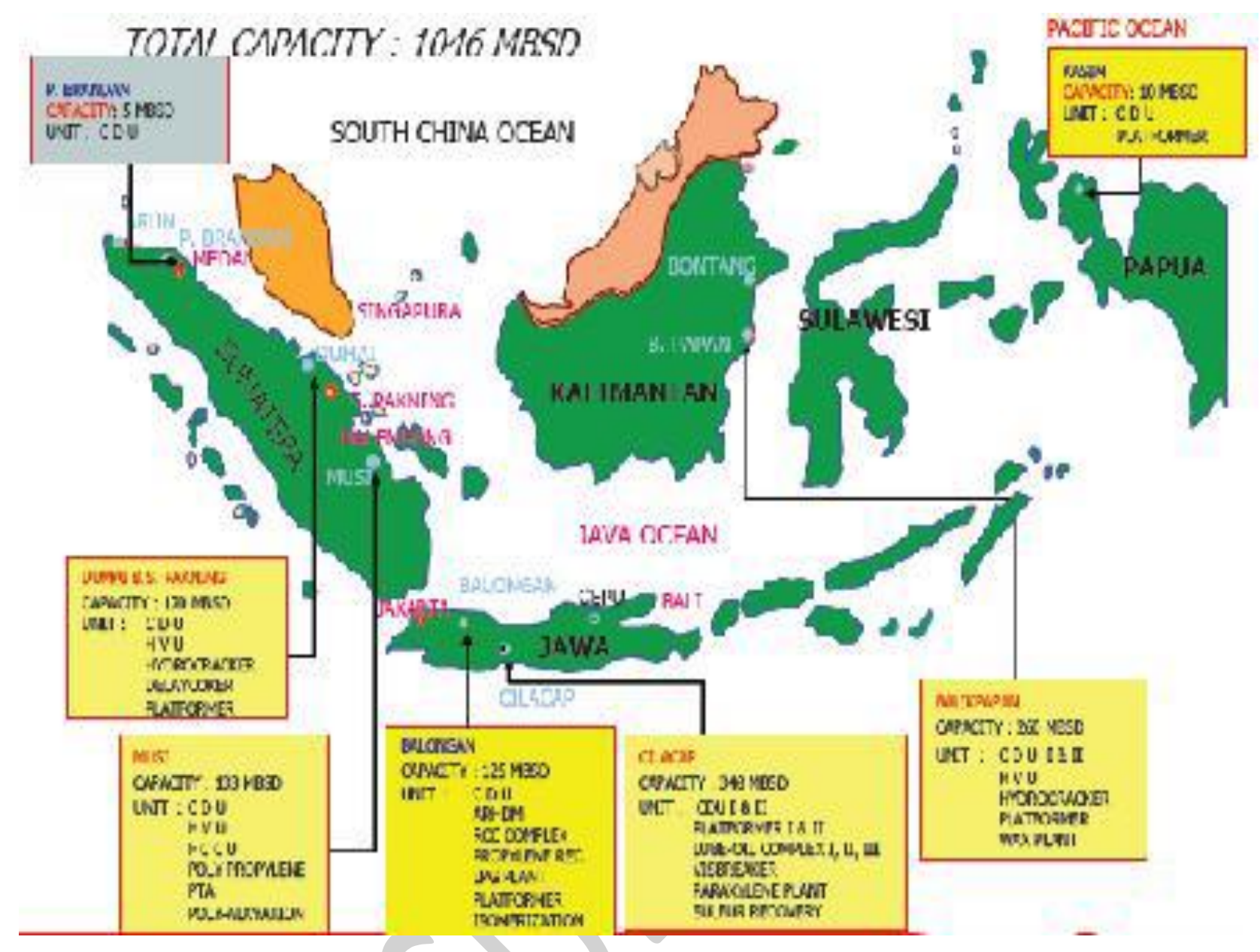

GAMBAR 1 - 1. Kilang Pengolahan Minyak Bumi dan Kapasitas Terpasang. By Risdiyanto, ST, MT

Secara singkat minyak mentah yang diolah, unit-unit yang ada dan produk yang dihasilkan oleh kilang-kilang minyak tersebut, adalah sebagai berikut :

\section{Kilang Musi (Plaju - Sungai Gerong)}

- Minyak Mentah,

- Unit - unit,

- Produk,
Palembang Selatan, Jambi, Minas, Talang, Akar-Pendopo, dan Lirik.

Distilasi (Atmosferis dan Hampa), Rengkahan, (Termal dan Katalitis), Polimerisasi, Alkilasi, Pembuatan Aspal.

Bensin, BB Pesawat, BB Jet, Kerosin, Solar, Minyak Diesel, Minyak Bakar, Parafin, dan Aspal. 


\section{Kilang Dumai}

- Minyak Mentah, Minas.

- Unit - unit, Distilasi (Atmosferis dan Hampa), LPG Recovery, Naphta hydrotreater, Platforming, dan Pabrik $\mathrm{H}_{2}$.

- Produk, Bensin Premium, Elpiji, Naphta, Kerosin, dan Solar.

\section{Kilang Sungai Pakning}

- Minyak Mentah,

Minas, dan Pedada.

- Unit - unit, Hanya Unit Distilasi Atmosferis.

- Produk, Naphta, Kerosin, Solar, Residu (Belerang Rendah)

\section{Kilang Pangkalan Brandan}

- Minyak Mentah,

- Unit - unit,

- Produk,

\section{Kilang Cilacap}

- Minyak Mentah,

- Unit - unit,

- Produk,
Minas, dan Pedada.

Hanya Unit Distilasi Atmosferis.

Bensin, Kerosin, Solar, dan Residu
Arab (Arabian Light Crude), Arjuna, dan Attaka.

Distilasi (Atmosferis dan Hampa), Platforming, Hydrodesulfurisasi, Meroxtreating, Visbreaking, Propane deasphalting, Ekstraksi furfural, dan Dewaxing MEK.

Bensin, Elpiji, Avtur, Kerosin, Solar, Minyak Bakar, Minyak Pelumas, dan Aspal. 


\section{Kilang Balikpapan}

- Minyak Mentah,

Minas, Tanjung, Warukin, Bekapai, Sepinggan, Handil, Attaka, Arjuna, Samboja, Sangata, dan Sanga-sanga.

- Unit - unit,

Distilasi (Atmosferis dan Hampa), LPG Recovery, Naphta hydrotreater, Platforming, dan Pabrik $\mathrm{H}_{2}$.

- Produk, Bensin Premium, Elpiji, Avtur, Kerosin, Solar, Minyak Diesel, dan Minyak Bakar.

\section{Kilang Cepu}

- Minyak Mentah,

Kawengan, dan Ledok.

- Unit - unit,

Distilasi Atmosferis.

- Produk,

Naphta, Pertasol, Kerosin, Solar, dan Minyak Bakar.

\section{Kilang Balongan (Exor I)}

- Minyak Mentah,

- Unit - unit,

- Produk,

\section{Kilang Kasim}

- Minyak Mentah,

- Unit - unit,

- Produk,
Duri $(80 \%)$ dan Minas (20\%).

Distilasi Atmosferis, Demetalisasi Residu Atmosferis, Hydrotreater Gas, Pabrik Belerang, dan Pabrik $\mathrm{H}_{2}$.

Elpiji, Bensin, Kerosin, Solar, Minyak Diesel, Belerang Dan Minyak Bakar.

Lapangan Kasim dan sekitarnya.

Distilasi Atmosferis.

Naphta, Pertasol, Kerosin, Solar, dan Minyak Bakar. 
Adapun kilang minyak bumi yang diolah oleh PT. PERTAMINA sekarang ini, adalah sebagai berikut,

1) JENIS MINYAK BUMI YANG DIOLAH OLEH KILANG PERTAMINA (Sumber : Refiring Technology, DIREKTORAT PENGOLAHAN PERTAMINA, Januari 2015)

Tabel. 1 - 2. Jenis Minyak Bumi Yang Diolah Kilang Pertamina

\section{DALAM NEGERI}

\begin{tabular}{|c|lc|}
\hline No. & \multicolumn{3}{|c|}{ Jenis } \\
\hline 1 & Minas / SLC & {$[\mathbf{S}=\mathbf{0}, \mathbf{1}]$} \\
\hline 2 & Duri & {$[\mathbf{S}=\mathbf{0}, \mathbf{2 5}]$} \\
\hline 3 & Jatibarang & {$[\mathbf{S}=\mathbf{0}, \mathbf{1 5}]$} \\
\hline 4 & Madura & {$[\mathbf{S}=\mathbf{0}, \mathbf{1 3}]$} \\
\hline 5 & Arjuna & {$[\mathbf{S}=\mathbf{0}, \mathbf{1 2}]$} \\
\hline 6 & Handil & {$[\mathbf{S}=\mathbf{0}, \mathbf{1 1}]$} \\
\hline 7 & Ramba & {$[\mathbf{S}=\mathbf{0}, \mathbf{0 8}]$} \\
\hline 8 & Tuban / Mudi & {$[\mathbf{S}=\mathbf{0}, \mathbf{3 4}]$} \\
\hline 9 & Belida & {$[\mathbf{S}=\mathbf{0}, \mathbf{1 7}]$} \\
\hline 10 & Walio & {$[\mathbf{S}=\mathbf{0 , 6 6}]$} \\
\hline
\end{tabular}

Tabel. 1 - 3. Jenis Minyak Bumi Yang Diolah Kilang Pertamina

\section{LUAR NEGERI}

\begin{tabular}{|cll|}
\hline No. & Jenis & \\
\hline 1 & ALC (Arabian Light) & {$[\mathbf{S}>33]$} \\
\hline 2 & Saharan & {$[\mathbf{S}=\mathbf{0}, \mathbf{1 1}]$} \\
\hline 3 & Tapi (Malaysia) & {$[\mathbf{S}=\mathbf{0}, 05]$} \\
\hline 4 & Nile Bland (Sudan) & {$[\mathbf{S}=\mathbf{0}, 2]$} \\
\hline 5 & Ba Ho (Vietnam) & {$[\mathbf{S}=0,04]$} \\
\hline 6 & Bonny Light (Nigeria) & {$[\mathbf{S}=0,14]$} \\
\hline 7 & Tengis (Kazakhstan) & {$[\mathbf{S}=\mathbf{0}, 12]$} \\
\hline
\end{tabular}

Sulfur $<0,5$ berat (sweet crude)

Sulfur $0,5-1,0$ berat (medium crude)

Sulfur $>1,0$ berat (high sulfur crude) 


\section{2) PERUBAHAN MINYAK BUMI YANG DIOLAH OLEH PERTAMINA}

(Sumber : Refiring Technology, DIREKTORAT PENGOLAHAN PERTAMINA, Januari 2015)

Tabel. 1 - 4. Perubahan Minyak Bumi Yang Diolah Kilang Pertamina

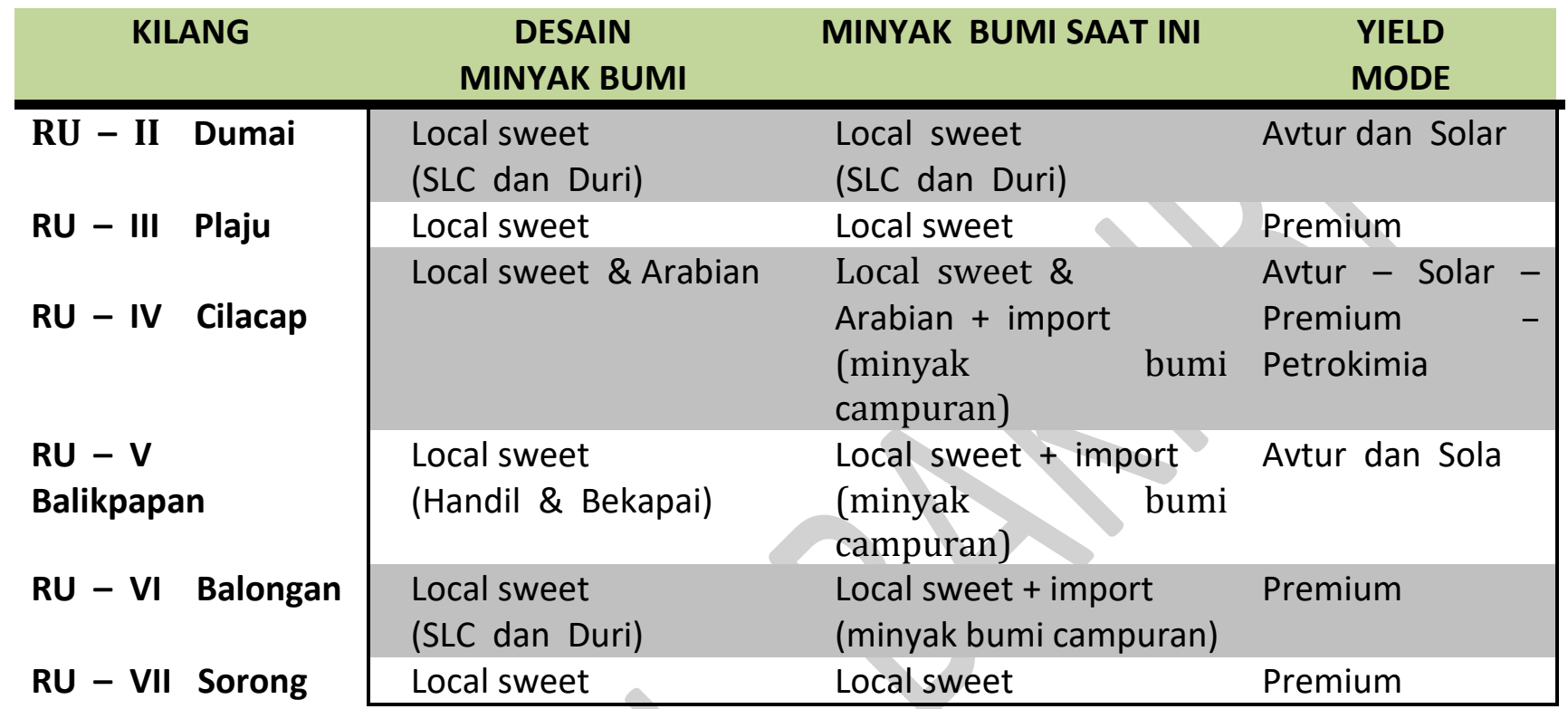

Keterangan, Kilang dirancang untuk mengubah Minyak Mentah lokal, Dibutuhkan untuk dapat mengolah minyak mentah import. 


\section{B A B II \\ TEORI DASAR MINYAK BUMI}

\section{DEFINISI MINYAK BUMI}

Minyak bumi, adalah suatu campuran yang sangat kompleks, yang utamanya terdiri dari senyawa-senyawa hidrokarbon, yaitu senyawa-senyawa organik yang setiap molekulnya hanya mempunyai unsur karbon dan hydrogen saja.

Minyak bumi banyak mengandung hidrokarbon, tetapi terdapat juga unsur-unsur belerang, vanadium, nikel, besi, dan tembaga. Air dan garam hampir selalu terdapat dalam minyak bumi dalam keadaan terdispersi. Bahan-bahan bukan hidrokarbon ini, biasanya dianggap sebagai kotoran, karena pada umumnya akan memberikan gangguan dalam proses pengolahan minyak bumi dalam kilang minyak dan berpengaruh buruk (kerugian) terhadap suatu produk.

Baik senyawa hidrokarbon maupun senyawa bukan hidrokarbon, keduanya akan berpengaruh dalam menentukan cara-cara pengolahan yang dilakukan dalam kilang minyak.

\section{KOMPOSISI MINYAK BUMI}

\section{SENYAWA HIDROKARBON}

Senyawa hidrokarbon sangat banyak jumlahnya dalam minyak bumi, sehingga dikelompokkan menjadi 3 (tiga) golongan senyawa hidrokarbon, yairu senyawa hidrokarbon Paraffin, Naften, dan Aromat.

\subsection{Senyawa Hidrokarbon Parafin}

Senyawa hidrokarbon jenuh, dengan rumus $\mathbf{C}_{n} \mathbf{H}_{2 n}+2$. Senyawa ini mempunyai sifat kimia yang stabil pada suhu biasa dan tidak bereaksi dengan asam sulfat pekat dan asam sulfat berasap, larutan alkali pekat, asam nitrat, maupun oksidator kuat seperti asam khroma, kecuali senyawa yang mempunyai atom karbon tersier. Bereaksi lambat dengan khlor dengan bantuan sinar matahari, serta bereaksi dengan khlor dan brom jika ada katalis. 
Senyawa hidrokarbon parafin, sampai dengan empat buah atom karbon pada keadaan standard (STP) berupa gas. Metan dan Etan adalah zat utama yang terdapat dalam gas alam, sedangkan propan, butan, dan i - butan merupakan komponen utama elpiji. Senyawa hidrokarbon parafin, dengan lima sampai enam belas buah atom karbon pada keadaan standard berupa cairan, dan terdapat dalam fraksi nafta, bensin, kerosin, solar, minyak diesel, dan minyak bakar. Senyawa hidrokarbon parafin, dengan lebih dari enam belas buah atom karbon pada keadaan standard berupa zat padat.

\subsection{Senyawa Hidrokarbon Naften}

Senyawa hidrokarbon jenuh dengan rumus $\mathbf{C}_{\mathbf{n}} \mathbf{H}_{2 n}$. Karena senyawa hidrokarbon ini mempunyai sifat kimia seperti senyawa hidrokarbon parafin dan mempunyai struktur molekul siklis, maka senyawa ini disebut juga senyawa sikloparafin. Senyawa hidrokarbon naften yang terdapat dalam minyak bumi adalah siklopentan dan sikloheksan, yang terdapat dalam fraksi nafta dan fraksi minyak bumi dengan titik didih lebih tinggi. Walaupun jumlah atom karbon dalam cincin naften dapat mempunyai harga $3,4,5,6,7$, dan 8 , namun umumnya dianggap bahwa senyawa naften dalam fraksi minyak bumi hanyalah senyawa naften yang mempunyai cincin dengan 5 dan 6 atom karbon, karena terbukti senyawa naften inilah yang dapat diisolasi dari fraksi minyak bumi.

Di samping senyawa naften sederhana, dalam minyak bumi khususnya dalam fraksi beratnya, juga terdapat senyawa naften polisiklis, seperti dekalin atau dekahidronaftalen.

\subsection{Senyawa Hidrokarbon Aromat}

Senyawa hidrokarbon tidak jenuh dengan rumus umum $\mathbf{C}_{\mathbf{n}} \mathbf{H}_{2 n-6}$, sehingga senyawa ini mempunyai sifat kimia yang sangat reaktif. Senyawa ini mudah dioksidasi menjadi asam, dapat mengalami reaksi substitusi atau reaksi adisi tergantung kepada kondisi reaksi. Hanya sedikit sekali minyak mentah yang mengandung senyawa aromat dengan titik didih rendah. Minyak mentah yang berasal dari Sumatera dan Kalimantan yang mempunyai kandungan senyawa aromat yang tinggi.

Disamping senyawa hidrokarbon aromat sederhana benzene, dalam minyak mentah juga terdapat senyawa hidrokarbon poliaromat seperti naftalen dan antrasen, terutama dalam fraksi beratnya. 


\subsection{Senyawa Hidrokarbon Monoolefin}

Senyawa ini mempunyai rumus umum $\mathbf{C}_{\mathbf{n}} \mathbf{H}_{2 n}$ dan merupakan senyawa hidrokarbon yang tidak jenuh dengan sebuah ikatan rangkap dua. Monoolefin dianggap tidak terdapat dalam minyak mentah, tetapi sedikit-banyaknya terbentuk dalam distilasi minyak mentah dan banyak terbentuk dalam proses rengkahan, sehingga bensin rengkahan mengandung banyak senyawa monoolefin. Senyawa hidrokarbon akan mulai mengalami rengkahan apabila dipanaskan pada suhu sekitar 680 o $\mathrm{F}$. Karena mempuyai ikatan rangkap, maka senyawa monoolefin adalah reaktif, sehingga banyak digunakan sebagai bahan dasar utama dalam industri petrokimia, seperti etilen $\left(\mathrm{C}_{2} \mathrm{H}_{2}\right)$ dan propilen $\left(\mathrm{C}_{3} \mathrm{H}_{6}\right)$.

\subsection{Senyawa Hidrokarbon Diolefin}

Senyawa hidrokarbon Diolefin mempunyai rumus umum $\mathbf{C}_{n} \mathbf{H}_{2 n}-2$ dan merupakan senyawa tidak jenuh dengan dua buah ikatan rangkap dua. Seperti halnya dengan monoolefin, senyawa ini tidak terdapat dalam minyak mentah tetapi terbentuk dalam proses rengkahan. Senyawa diolefin tidak stabil, sangat reaktif dan cenderung akan berpolimerisasi dan membentuk damar.

\section{A. DISTRIBUSI SENYAWA HIDROKARBON DALAM MINYAK BUMI}

Dalam minyak bumi ternyata bahwa senyawa-senyawa hidrokarbon parafin, naften, dan aromat tidak terdistribusi secara merata dalam sebuah fraksi. Senyawa hidrokarbon naften polisiklis dan poliaromatis tidak terdapat dalam fraksi ringan tetapi terdapat dalam fraksi berat.

\section{B. KOMPLEKSITAS KOMPOSISI MINYAK BUMI}

Walaupun senyawa hidrokarbon yang menyusun minyak bumi hanyalah senyawa hidrokarbon parafin dan aromat, namun komposisi minyak bumi adalah sangat kompleks. Hal ini disebabkan karena senyawa-senyawa tersebut selain berupa senyawa murni, juga terdapat senyawa gabungan antara senyawa hidrokarbon parafin - naften, parafin - aromat, naften - naften (polinaften), naften - aromat, aromat - aromat (poliaromat), dan parafin - naften - aromat dan kemungkinan kombinasi yang lain. 
Di samping itu, adanya isomeri dalam senyawa hidrokarbon, yang menyebabkan komposisi minyak bumi menjadi lebih kompleks lagi. Senyawa - senyawa isomer adalah senyawa-senyawa yang mempunyai rumus molekul yang sama tetapi struktur molekulnya berbeda. Jumlah senyawa isomer dalam senyawa hidrokarbon sangat meningkat dengan bertambahnya jumlah atom karbon. Jumlah isomer yang mungkin untuk senyawa hidrokarbon parafin dapat dilihat pada table berikut,

Tabel. 2 - 1. Jumlah Isomer dalam senyawa Hidrokarbon Parafin.

\begin{tabular}{|rr|}
\hline Jumlah Atom Karbon & Jumlah Isomer \\
\hline 4 & 2 \\
\hline 5 & 3 \\
\hline 6 & 5 \\
\hline 7 & 9 \\
\hline 8 & 18 \\
\hline 9 & 35 \\
\hline 12 & 355 \\
\hline 15 & 4,347 \\
\hline 18 & 60,523 \\
\hline 25 & $36,797,588$ \\
\hline
\end{tabular}

Holleman, “Leerboek der Organische Chemie”, Wolters 


\section{SENYAWA BUKAN HIDROKARBON}

Senyawa bukan hidrokarbon yang terdapat dalam minyak bumi dan produknya adalah senyawa organik yang mengandung atom unsur belerang, oksigen, nitrogen, dan logamlogam. Lazimnya senyawa ini dianggap sebagai pengotor karena pengaruhnya yang tidak baik selama proses pengolahan minyak bumi dalam kilang minyak, seperti korosi dan peracunan katalis ataupun pengaruh buruk terhadap mutu produk. Karena pengotor ini dapat larut dengan minyak bumi atau produknya, maka pengotor ini disebut Pengotor Oleofilik. Disamping itu, air dan garam-garam yang terlarut (terdispersi) dalam minyak mentah dan tidak larut dalam fase minyak, disebut Pengotor Oleofobik.

\subsection{Senyawa Belerang}

Disamping sebagai senyawa belerang, di dalam minyak bumi belerang dapat juga terdapat sebagai unsur belerang yang terlarut, karena sedikit banyak belerang dapat larut dalam minyak bumi. Kadar belerang dalam minyak mentah berkisar antara $0,04-6 \%$.

Minyak bumi Indonesia, terkenal sebagai minyak bumi berkadar belerang rendah hingga sedang, yang umumnya kandungannya kurang dari $1 \%$ berat. Apabila minyak mentah didistilasi, maka belerang akan terdistribusi sedemikian sehingga makin berat fraksinya kandunga belerangnya makin besar, dan kira-kira $95 \%$ berat dari belerang yang berasal dari umpan akan terdapat dalam fraksi minyak gas dan residu, seperti pada tabel berikut,

Tabel. 2 - 2. Distribusi Belerang dalam produk hasil distilasi minyak mentah.

\begin{tabular}{|c|c|c|c|c|c|}
\hline \multirow{2}{*}{ Minyak Mentah } & \multirow{2}{*}{$\begin{array}{l}\% \text { Berat S dalam } \\
\text { Minyak Mentah }\end{array}$} & \multirow[b]{2}{*}{ Bensin } & \multicolumn{3}{|c|}{$\%$ Berat $\mathbf{S}$ dalam Produk } \\
\hline & & & Kerosin & M gas & Residu \\
\hline Timur Tengah & 0,15 & 0,3 & 3,6 & 38,6 & 57,7 \\
\hline Texas Timur & 0,36 & 0,9 & 1,3 & 15,4 & 82,4 \\
\hline Venezuela Timur & 0,55 & 0,5 & 1,7 & 15,5 & 82,3 \\
\hline Iran & 1,4 & 1,1 & 1,5 & 12,6 & 84,8 \\
\hline Texas Barat & 2,0 & 1,8 & 4,2 & 14,8 & 79,2 \\
\hline Venezuela Barat & 2,2 & 0,05 & 0,05 & 6,6 & 92,8 \\
\hline Kuwait & 2,45 & 0,1 & 0,8 & 9,5 & 89,6 \\
\hline
\end{tabular}

Kontawa, ‘Minyak Bumi - Pengklasifikasian dan Evaluasi”, Lemigas 1995. 
Beberapa macam kerugian dengan adanya senyawa belerang dalam minyak bumi,

\section{- Pencemaran Udara}

Umumnya, senyawa belerang memiliki bau yang tidak sedap, yaitu senyawa belerang yang mempunyai titik didih rendah, seperti hydrogen sulfid dan belerang dioksid dalam gas buang hasil pembakaran.

Selanjutnya pencemaran udara dapat juga terjadi karena gas belerang dioksid yang berasal dari gas buang terlarut dalam kabut, yaitu tetesan air dalam udara. Hal ini dikenal dengan nama smog, yang dapat terjadi di kota-kota industri besar yang selalu berkabut. Belerang dioksid yang berasal dari gas buang dapat juga mengakibatkan hujn asam.

\section{- Korosi}

Terjadi karena banyaknya senyawa belerang terutama terjadi pada suhu di atas $300{ }^{\circ} \mathrm{F}$. Korosi ini akan merusakkan alat-alat pengolahan dalam kilang minyak, khususnya alat-alat yang bekerja pada suhu tinggi. Pada suhu rendah, senyawa belerang yang bersifat korosif adalah hydrogen sulfid dan beberapa senyawa sulfid.

Selanjutnya, gas belerang dioksid dalam gas buang yang terjadi pada pembakaran bahan bakar minyak akan merusakkan cerobong baja dan saluran pembuangan gas buang hasil pembakaran mesin. Apabila gas ini bereaksi dengan air, akan menghasilkan asam.

\section{- Menurunkan Angka Oktan Bensin}

Penurunan angka oktan bensin oleh senyawa belerang tergantung pada jumlah dan type senyawa belerang, yang menunjukkan bahwa $0,1 \%$ belerang akan menurunkan angka oktan 0 - 2 satuan angka oktan. 


\section{- Menurunkan Suseptibilitas Bensin terhadap TEL}

Yang dimaksud dengan Suseptibilitas (susceptibility) bensin terhadap TEL, yaitu kenaikan angka oktan bensin apabila kedalam satu gallon Amerika bensin ditambahkan satu centimeter kubik TEL. fungsi TEL adalah untuk menaikkan angka oktan bensin, sehingga untuk memperoleh angka oktan bensin dengan harga tertentu, maka bensin dengan kandungan belerang yang lebih tinggi memerlukan jumlah TEL yang lebih banyak dibandingkan dengan bensin yang mempunyai kandungan belerang yang lebih rendah, dan ini menyebabkan biaya menjadi tinggi (mahal).

\section{- Meracuni Katalis}

Pada proses reforming katalitik nafta atau bensin untuk membuat nafta atau bensin dengan angka oktan yag tinggi, adanya belerang dalam umpan nafta atau bensin dapat meracuni katalis platina. Sehingga pada proses reforming yang menggunakan katalis platina ini menjadi suatu keharusan bahwa kandungan belerang dalam umpan harus dibatasi serendah mungkin, maksimum 0,2 ppm.

\subsection{Senyawa Oksigen}

Kadar oksigen dalam minyak bumi bervariasi, $0,1-2 \%$ berat. Oksidasi minyak bumi dengan oksigen karena kontak yang lama dengan udara juga dapat menaikkan kadar oksigen dalam minyak bumi.

Dalam minyak bumi, oksigen terutama terdapat sebagai asam organik yang terdistribusi dalam semua fraksi dengan konsentrasi yang tertinggi pada fraksi minyak gas. Asam organik tersebut terutama terdapat sebagai asam naftenat dan sebagian kecil sebagai asam alifatik. Disamping itu dalam distilat rengkahan daoat terdapat fenol dan kresol. Asam naftenat mempunyai sifat sedikit korosif dan mempunyai bau tidak enak.

\subsection{Senyawa Nitrogen}

Kadar nitrogen dalam minyak bumi umumnya rendah, berkisar $0,1-2 \%$ berat. Minyak yang mempunyai kadar belerang dan aspal tinggi, biasanya juga mempunyai kadar nitrogen tinggi. Senyawa nitrogen terdapat dalam semua fraksi minyak bumi, tetapi konsentrasinya makin tinggi dalam fraksi-fraksi yang mempunyai titik didih yang tinggi. 
Adapun kerugian yang diakibatkan oleh adanya senyawa nitrogen yang terdapat dalam minyak bumi dan produknya, adalah sebagai berikut,

- Menurunkan aktivitas katalis yang digunakan dalam proses rengkahan, reforming, polimerisasi, dan isomerisasi.

- Kerosin yang jernih seperti air pada waktu distilasi, warnanya akan berubah menjadi kemerahan jika terkena sinar matahari.

- Nitrogen dalam bensin juga akan mempercepat pembentukan damar dalam karburator.

- Menyebabkan terjadinya endapan dalam minyak bakar pada penyimpanannya.

\subsection{Senyawa Logam}

Logam sangat sedikit jumlahnya dalam minyak bumi, antara 5 - 400 bagian per juta, maka adanya logam dalam minyak bumi pada umumnya tidak menimbulkan permasalahan, kecuali beberapa beberapa macam logam seperti besi, nikel, vanadium dan arsen yang walaupun jumlahnya sangat sedikit., namun dapat meracuni beberapa katalis. Disamping itu juga logam vanadium yang terdapat dalam miyak bakar dapat menyebabkan korositurbin gas dan pipa-pipa pembangkit uap, merusak batu tahan api dinding dapur dan menurunkan mutu produk pecah belah dalam industri keramik.

Logam garam anorganik yang dapat larut dalam air, seperti garam khloria dan sulfat dari logam natrium, kalium, magnesium, dan kalsium, terdapat dalam minyak bumi dalam keadaan terdispersi. Dalam distilasi minyak mentah, senyawa logam cenderung untuk berkumpul dalam fraksi residu.

\section{KLASIFIKASI MINYAK BUMI}


Setiap ladang (lokasi eksploitasi) minyak menghasilkan minyak mentah yang berbeda dengan minyak mentah yang dihasilkan dari ladang minyak lainnya, apalagi komposisi kimia minyak mentah yang memiliki variasi yang tidak terbatas (amat sangat banyak) sehingga sangat sukar untuk diklasifikasikan, bahkan hingga sekarang klasifikasi minyak mentah belum sempurna. Tetapi, dapat diklasifikasikan mendakati sempurna, agar dapat diperoleh suatu gambaran mengenai produk-produk yang dihasilkan dari klasifikasi atau golongan minyak mentah tersebut.

Berikut ini, akan diuraikan beberapa sistem atau pendekatan untuk mengklasifikasikan minyak mentah.

\section{KLASIFIKASI BERDASARKAN BERAT JENIS}

Berat jenis minak mentah dalam IImu Perminyakan, dibahasakan dengan Gravitas API. Klasifikasi berdasarkan berat jenis, merupakan klasifikasi yang paling mudah, karena jika berat jenis minyak mentah rendah, maka minyak mentah tersebut cenderung mengandung jumlah fraksi ringan yang besar. Minyak mentah dengan gravitas $35^{\circ} \mathrm{API}$ lebih "Berharga" daripada minyak mentah dengan gravitas $30{ }^{\circ} \mathrm{API}$, karena minyak mentah dengan gravitas $35{ }^{\circ} \mathrm{API}$ mengandung banyak fraksi ringan (bensin, kerosin) dibandingkan dengan gravitas $30^{\circ} \mathrm{API}$.

Berdasarkan berat jenis, minyak mentah dibagi dalam 5 (lima) jenis minyak mentah, yaitu minyak mentah ringan, minyak mentah ringan sedang, minyak mentah berat sedang, minyak mentah berat, dan minyak mentah sangat berat, seperti terlihat pada table berikut,

Tabel. 2- 3, Klasifikasi Minyak Bumi Berdasarkan Gravitasi API atau Berat Jenis

\begin{tabular}{|c|c|c|c|c|}
\hline \multirow{2}{*}{$\begin{array}{c}\text { JENIS } \\
\text { MINYAK MENTAH }\end{array}$} & \multicolumn{2}{|c|}{ Gravitasi API } & \multicolumn{2}{|c|}{ Berat Jenis } \\
\hline & Dari & Sampai & Dari & Sampai \\
\hline Ringan & $>39,0$ & & $<0,830$ & \\
\hline Ringan Sedang & 39,0 & 35,0 & 0,830 & 0,850 \\
\hline Berat Sedang & 35,0 & 35,0 & 0,850 & 0,865 \\
\hline Berat & 35,0 & 24,8 & 0,865 & 0,905 \\
\hline Sangat Berat & $<24,8$ & & $>0,905$ & \\
\hline
\end{tabular}

Kontawa, 'Minyak Bumi - Pengklasifikasian dan Evaluasi”, Lemigas 1995.

\section{KLASIFIIKASI BERDASARKAN KANDUNGAN PARAFIN DAN ASPAL}


Berdasarkan kandungan parafin dan aspal, minyak mentah dapat dibagi dalam 3 (tiga) golongan dasar minyak mentah, yaitu:

\subsection{Minyak mentah dasar Parafin}

\subsection{Minyak mentah dasar Aspal}

\subsection{Minyak mentah dasar Campuran (Tengahan)}

Sebagian besar minyak mentah (90\% minyak mentah) termasuk dalam golongan minyak mentah dasar campuran, sedangkan $10 \%$ lainnya termasuk dalam golongan minyak mentah dasar parafin dan aspal.

\section{KLASIFIKASI BERDASARKAN KOMPOSISI KIMIA}

Klasifikasi ini diajukan oleh Sachanen, berdasarkan komposisi kimia fraksi minyak bumi khusus untuk daerah (range) titik didih antara $250-300^{\circ} \mathrm{C}$, seperti pada table berikut,

Tabel. 2 - 4. Klasifikasi Minyak Mentah Menurut Sachanen

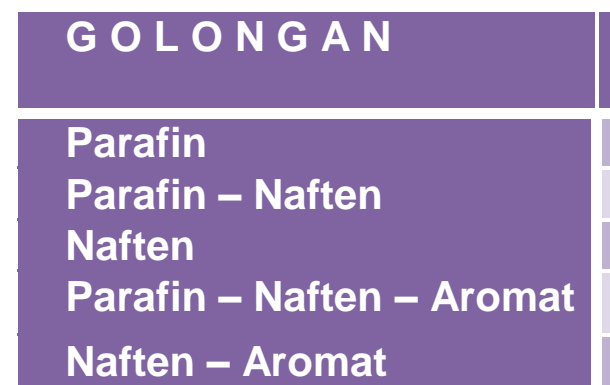

\section{$\%$ Parafin}

$46-61$

$42-45$

$16-26$

$27-35$

$0-8$
KOMPOSISI FRAKSI $250-300^{\circ} \mathrm{C}$ $\%$ Naften $\%$ Aromat $\%$ Aspal

Van Nes \& Van Westen, “Aspects of The Contitution of Mineral Oils”, Elsevier.

Kesulitan dalam klasifikasi ini, adalah jika fraksi yang mendidih di atas $200{ }^{\circ} \mathrm{C}$, maka molekul-molekulnya umumnya tidak terdapat dalam keadaan murni (molekulnya dalam keadaan molekul gabungan). Molekul naften dan aromat murni sangat jarang dijumpai, dan Senyawa siklis umumnya mengandung rantai cabang parafin, kadang mengandung cincin aromat, dan cincin naften berdampingan.

\section{KLASIFIKASI MENURUT U. S. BUREAU OF MINES}


Klasifikasi minyak bumi yang sekarang digunakan, adalah Klasifikasi menurut dan Garton dari U.S. Bureau of Mines, dengan dasar klasifikasinya menggunakan Gravitasi API Kunci Nomor 1 dan Nomor 2, yang diperoleh dengan menggunakan alat Distilasi Hempel Standard.

- Fraksi Kunci Nomor 1, adalah fraksi minyak bumi yang mendidih pada suhu antara $482-527^{\circ} \mathrm{F}$ atau $250-275^{\circ} \mathrm{C}$, pada tekanan 1 atmosfer. Fraksi ini termasuk dalam Fraksi Kerosin.

- Fraksi Kunci Nomor 2, adalah fraksi minyak bumi yang mendidih pada suhu antara $527-572{ }^{\circ} \mathrm{F}$ atau $275-300^{\circ} \mathrm{C}$, pada tekanan $40 \mathrm{mmHg}$. Fraksi ini termasuk dalam Fraksi Minyak Pelumas.

Secara teoritis, terdapat 9 (Sembilan) golongan dasar minyak mentah yang dapat dilihat pada Tabel. di bawah, tetapi dalam prakteknya hanya 7 (tujuh) golongan dasar minyak mentah yang dikenal. Dua golongan lainnya, yaitu golongan dasar Parafin - Naften, dan Naften - Parafin, adalah golongan minyak mentah yang belum pernah ditemukan atau dijumpai hingga sekarang.

Tabel. 2 - 5. Klasifikasi Minyak Bumi menurut U.S. Bureau of Mines

\begin{tabular}{lcc}
\hline & \multicolumn{2}{c}{ Gravitasi API } \\
\hline Golongan Dasar & $\begin{array}{c}\text { Fraksi Kunci } \\
\text { Nomor } \mathbf{1}\end{array}$ & $\begin{array}{c}\text { Fraksi Kunci } \\
\text { Nomor 2 }\end{array}$ \\
$\mathbf{1}$ Parafin - Parafin & $>40$ & $>30$ \\
$\mathbf{2}$ Parafin - tengahan & $>40$ & $20-30$ \\
3 Parafin - Naften & $>40$ & $<20$ \\
$\mathbf{4}$ tengahan - Parafin & $33-40$ & $>30$ \\
$\mathbf{5}$ tengahan - tengahan & $33-40$ & $20-30$ \\
$\mathbf{6}$ tengahan - Naften & $33-40$ & $<20$ \\
$\mathbf{7}$ Naften - Parafin & $<33$ & $>30$ \\
$\mathbf{9}$ Naften - tengahan & $<33$ & $20-30$ \\
\hline
\end{tabular}

Kontawa, 'Minyak Bumi - Pengklasifikasian dan Evaluasi’, Lemigas 1995.

\section{KLASIFIKASI MENURUT DISTRIBUSI ATOM KARBON}


Klasifikasi ini diajukan oleh Van Ness dan Van Westen, didasarkan pada distribusi karbon parafinik, naftenik, dan aromatik dalam minyak mentah.

Klasifikasi ini menggunakan diagram segitiga, yang ketiga titik sudutnya masing-masing menunjukkan $100 \%$ Karbon Parafin $\mathrm{C}_{\mathbf{P}}, 100 \%$ Karbon Naften $\mathrm{C}_{\mathrm{N}}$, dan $100 \%$ Karbon Aromat $\mathbf{C}_{\mathrm{A}}$.

Sebuah titik yang terdapat dalam diagram, menunjukkan distribusi karbon parafin, naften, dan aromat, seperti yang ditunjukkan dalam gambar $2-1$.

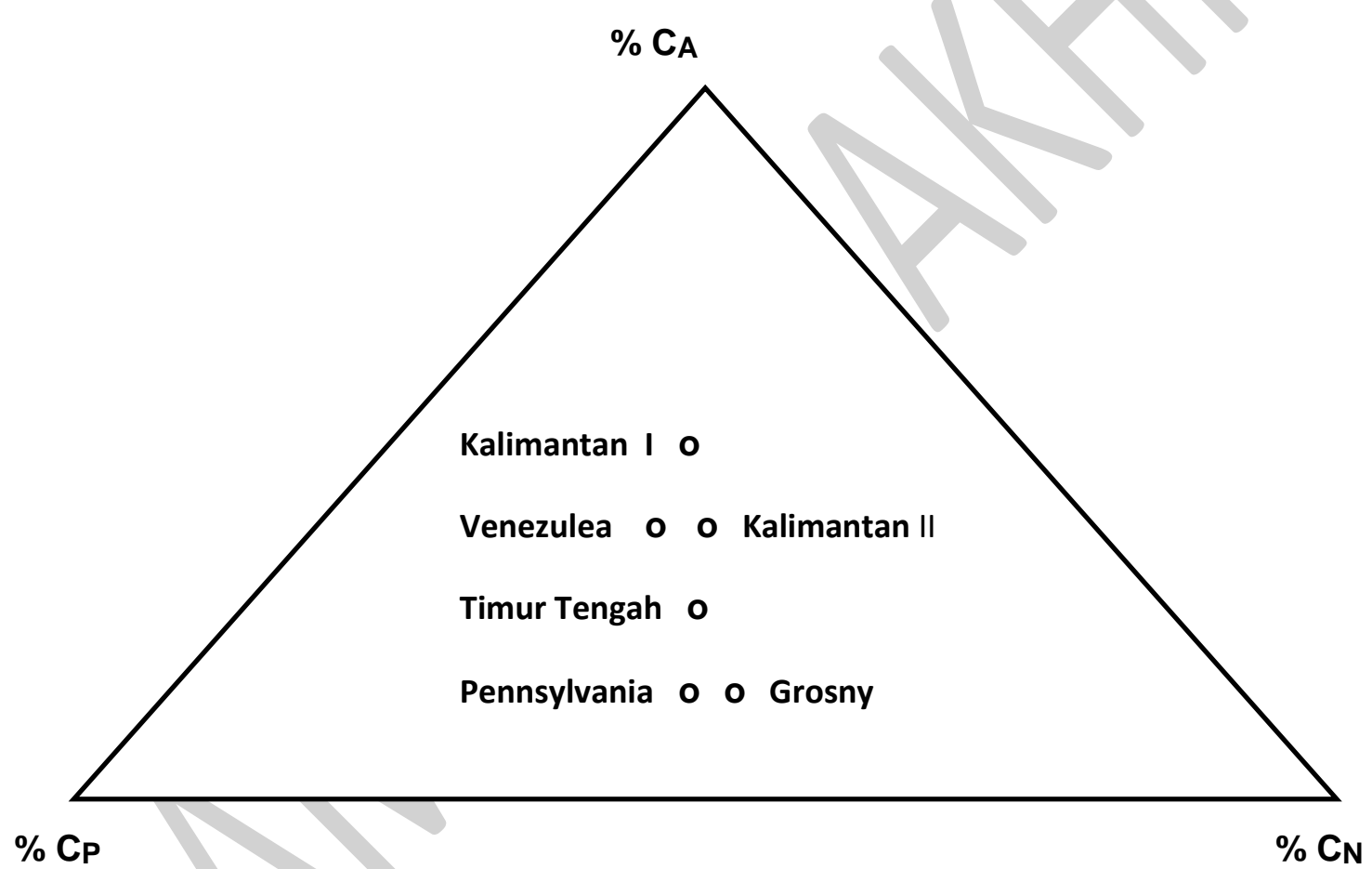

Gambar. 2 - 1. Distribusi karbon beberapa minyak (Van Nes \& Van Westen, "Aspects of The Constitution of Mineral Oils", Elsevier.

6. KLASIFIKASI BERDASARKAN FAKTOR KARAKTERISASI 
Klasifikasi ini diajukan oleh Watson dari Universal Oil Product Company, mendefiisikan tentang faktor karakterisasi Watson $\mathbf{K}$ sebagai berikut:

$$
\mathrm{K}=\frac{\sqrt[3]{\mathrm{T}_{\mathrm{B}}}}{S}
$$

Dimana, $\quad \mathrm{T}_{\mathrm{B}}$, adalah Titik Didih rata-rata tengahan dalam ${ }^{\circ} \mathrm{R}$.

S, adalah Berat jenis pada $60 / 60^{\circ} \mathrm{F}$.

Klasifikasi ini, juga berlaku untuk fraksi minyak bumi langsung (straight run fractions). Adapun faktor karakterisasi untuk berbagai golongan dasar minyak mentah, adalah sebagai berikut

$\begin{array}{ll}\text { Minyak mentah dasar Parafin, } & \mathrm{K}>12,1 \\ \text { Minyak mentah dasar tengahan, } & \mathrm{K}=11,5-12,1 \\ \text { Minyak mentah dasar Naften, } & \mathrm{K}=10,5-11,45 \\ \text { Minyak mentah dasar Aromat, } & \mathrm{K}<10,5\end{array}$

\section{KLASIFIKASI BERDASARKAN INDEKS KORELASI}

Klasifikasi ini dikembangkan oleh H. M. Smith dari U.S. Bureau of Mines, yang berlaku untuk fraksi minyak bumi.

Indeks ini, dijabarkan dalam persamaan empirik, sebagai berikut :

$$
\text { I.K. }=473,7 \mathrm{~S}-456,8+48640 / \mathrm{K}
$$

Dimana, I.K, adalah indeks korelasi,

S, adalah gravitasi jenis pada $60 / 60^{\circ} \mathrm{F}$,

$\mathrm{K}$, adalah titik didih rata-rata dalam $\mathrm{K}$.

\section{KLASIFIKASI MINYAK BUMI LAINNYA}


Selain klasifikasi minyak bumi yang telah diuraikan di atas, ada beberapa cara klasifikasi lainnya, yaitu :

8.1. Klasifikasi Minyak Bumi berdasarkan Kandungan Belerang

- Minyak mentah dengan kandungan belerang rendah ( $<0,1 \%)$

- Minyak mentah dengan kandungan belerang sedang $(0,1-1,0 \%)$

- Minyak mentah dengan kandungan belerang tinggi ( > 1,0 \%)

8.2. Klasifikasi Minyak Bumi berdasarkan kandungan Hidrogen Sulfid

- Minyak mentah masam (sour crude)

- Minyak mentah manis (sweet crude)

Batas kandungan hydrogen sulfide adalah $0,05 \mathrm{ft}^{3} / 100$ galon minyak mentah.

\section{SIFAT - SIFAT UMUM MINYAK BUMI}

Sifat-sifat umum minyak bumi, terlihat pada tabel berikut,

Tabel. 2 - 6, Sifat - sifat Umum Minyak Bumi

\section{SIFAT - SIFAT}

Gravitasi API

Kandungan Nafta

Angka Oktan Bensin

Titik Asap Bensin

Angka Cetan Solar

Titik Tuang Minyak Pelumas

Indeks Viskositas Minyak Pelumas

\section{Dasar PARAFIN Dasar NAFTEN}

\begin{tabular}{|l|l|}
\hline Tinggi & Rendah \\
\hline Tinggi & Rendah \\
\hline Rendah & Tinggi \\
\hline Tinggi & Rendah \\
\hline Tinggi & Rendah \\
\hline Tinggi & Rendah \\
\hline Tinggi & Rendah \\
\hline
\end{tabular}

sifat- 


\section{B A B III}

\section{PRODUKSI MINYAK BUMI}

Produksi Minyak bumi memiliki puluhan jenis produk, seiring dengan perkembangan zaman dan teknologi, belum termasuk produk petrokimia yang dihasilkan oleh industriindustri petrokimia.

Produk minyak bumi yang dihasilkan oleh kilang minyak untuk dipasarkan, haruslah memenuhi spesifikasi pemasaran. Spesifikasi pemasaran produk minyak bumi untuk berbagai negara sangatlah berbeda, kecuali untuk bensin penerbangan dana bahan bakar jet, yang spesifikasinya disesuaikan dengan spesifikasi Internasional.

Spesifikasi pemasaran, adalah batas - batas tentang sifat yang harus dipenuhi oleh produk-produk minyak bumi yang berada di pasaran, yang merupakan hasil kompromi antara sifat kinerja produk minyak bumi dengan kemampuan kilang minyak untuk menghasilkan produk dari minyak mentah yang tersedia.. Khusus Indonesia, spesifikasi produk bahan bakar minyak ditetapkan sesuai dengan Keputusan Direktur Jenderal Minyak dan Gas Bumi, yang dapat dilihat pada lampiran.

Ada beberapa cara penggolongan produk 'jadi" yang dihasilkan oleh kilang minyak. Diantaranya produk Bahan Bakar Minyak (BBM) dan produk Non BBM. Yang termasuk produk BBM, adalah Bensin Penerbangan, Bensin Motor, Bahan Bakar Jet, Kerosin, Solar, Minyak Diesel, dan Minyak Bakar. Sedangkan yang termasuk produk Non BBM, adalah Elpiji (Liquefied Petroleum Gases - LPG), Pelarut Minyak Pelumas, Aspal, Parafin, Hitam Karbon (Carbon Black), dan Kokas.

Adapun pembagian dari produk "jadi" kilang minyak, adalah :

1. Produk volatil-elpiji (LPG) dan bensin alam.

2. Minyak ringan - bensin motor, bensin penerbangan, bahan bakar turbin penerbangan, pelarut, bahan bakar traktor, dan kerosin.

3. Distilat - solar, minyak diesel, dan minyak gas.

4. Minyak pelumas, mencakup bermacam jenis minyak pelumas.

5. Residu - minyak bakar, kokas petroleum, aspal, dan lain-lain.

6. Produk khusus - hidrokarbon, bahan kimia, insektisida, dan lain-lain. 
Dalam makalah kami ini, kami hanya membahas tentang produk "jadi" yang ada di negara tercinta kita, yaitu Indonesia.

Sebelum kami membahasnya, perkenan kami menampilkan gambar secara umum tentang proses refining.

\section{Gambar. 3-1. Proses Refinasi Minyak Bumi}

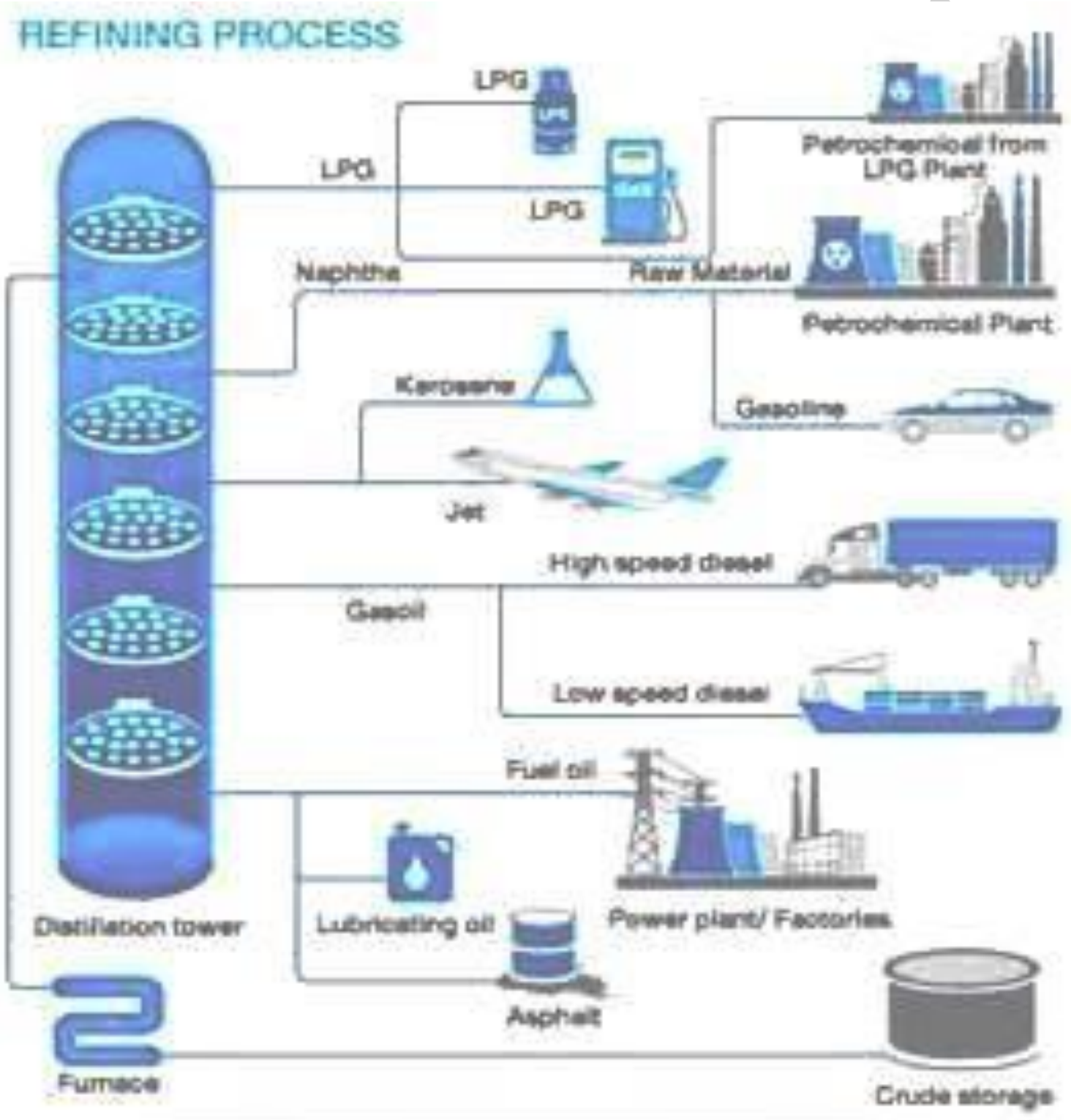




\section{EKSPLORASI DAN EKSPLOITASI MINYAK BUMI}

Sebelum membahas produksi minyak bumi, perkenankan kami menerangkan kegiatan atau proses sebelum produksi minyak bumi atau Pra-Produksi Minyak Bumi.

Dalam Pra-Produksi Minyak Bumi, kami kelompokkan dalam 2 (dua) tahap, yaitu : Tahap Eksplorasi (Bahan Mata Kuliah, Teknik Reservoar 1, Teknik Perminyakan ITB, 1993) dan Tahap Eksploitasi (Teknik Pengeboran 1, Teknik Perminyakan ITB, 1993).

\section{TAHAP EKSPLORASI}

\section{EKSPLORASI AWAL}

Pada tahap ini, awalnya para Ahli Geologi dan Geofisika mencari cadangan (depost) minyak bumi pada suatu daerah dan menentukan letak dan kedalaman cadangan (deposit) tersebut.

Kepastian bahwa daerah tersebut memiliki cadangan minyak bumi, maka oleh Ahli Reservoar (Teknik Perminyakan) menindaklanjuti data yang diterima dari Ahli Geologi (Teknik Geologi) dan Ahli Geofisika (Teknik Geofisika) tentang Kepastian adanya cadangan (deposit) minyak bumi, mulai menghitung Kadar atau Volume yang dikandung oleh cadangan (deposit) tersebut. Setelah menghitung dan menentukan Volume yang terdapat dalam cadangan (deposit) tersebut, kemudian Ahli Reservoar menghitung Biaya Operasional Pengambilan (Proses Ekploitasi) cadangan (deposit) tersebut (perhitungan biaya operasional ke atas atau tertinggi yang dibandingkan harga minimum minyak dunia). Jika hasil perhitungan menunjukkan, bahwa nilai dari cadangan (deposit) minyak bumi tersebut lebih besar atau lebih tinggi dari biaya operasional pengambilan (ekploitasi), maka cadangan (deposit) tersebut "Layak" untuk diambil (dieksploitasi). Sebaliknya, jika "Tidak Layak" (Biaya Operasional pengambilan lebih besar atau lebih tinggi dibandingkan nilai atau harga dari cadangan (deposit) tersebut), maka cadangan (deposit) minyak bumi tersebut tidak dilanjutkan ke tahap ekploitasi (dibiarkan).

Jika cadangan (deposit) minyak bumi tersebut telah dinyatakan "LAYAK" dan "UNTUNG" oleh Ahli Reservoar, maka masuklah ke tahap Ekplorasi Lanjut. 


\section{EKSPLORASI LANJUT}

Pada tahap ini, diawali oleh Ahli Formasi (Teknik Perminyakan). Ahli Formasi mempelajari Lapisan-lapisan Tanah, mulai lapisan tanah di permukaan hingga lapisan tanah di atas cadangan (deposit) minyak bumi tersebut. Tujuan yang dilakoni oleh Ahli Formasi, adalah untuk menentukan 'Di Mana" letak dari Benda-benda keras atau Batuan keras yang berada dalam lapisan tanah tersebut.

Maksud dari penentuan letak benda atau batuan keras tersebut, adalah agar Pipa Bor tidak tertabrak dan tidak bersinggungan dengan benda atau batuan keras tersebut. Jika Pipa Bor mengenai (menabrak) benda atau batuan keras tersebut, maka mengakibatkan rusaknya "mata" dari Pipa Bor tersebut, yang otomatis meningkatnya biaya operasional pengambilan.

Setelah Ahli Formasi menyelesaikan tugasnya (Data Formasi), kemudian Data tersebut diberikan kepada Ahli Pengeboran (Teknik Perminyakan dan Teknik Pertambangan) untuk selanjutnya masuk ke tahap pemgambilan (Eksploitasi).

Jadi, Data Formasi yang dihasilkan oleh Ahli Formasi, merupakan Data Fundamental bagi Ahli Pengeboran dan sebagai Data Acuan bagi Perusahaan Offshore (Kontraktor).

\section{TAHAP EKSPLOITASI}

Pada tahap ini, dimulailah Pengambilan (Eksplotasi) Minyak Bumi yang diawali dengan Pengeboran Minya Bumi, yang dilakukan oleh Perusahaan Offshore (Kontraktor) yang tentunya mempunyai Tim Ahli Pengeboran.

Minyak bumi atau minyak mentah yang diperoleh dari hasil Pengeboran (Ekploitasi), kemudian ditampung dan didistribusikan ke kilang minyak dan pabrik untuk diolah menjadi Produk yang berguna dan bermanfaat bagi umat manusia.

Demikianlah sekilas tentang Tahap Ekplorasi dan Tahap Ekploitasi, sebelum masuk ke tahap Produksi. 
Agar dapat dipahami keterangan di atas, Secara umum marilah kita perhatikan gambar $3-2$, tentang proses pembuatan BBM.

Gambar. 3 - 2. Proses Pembuatan BBM

Proses/Alat

Produk

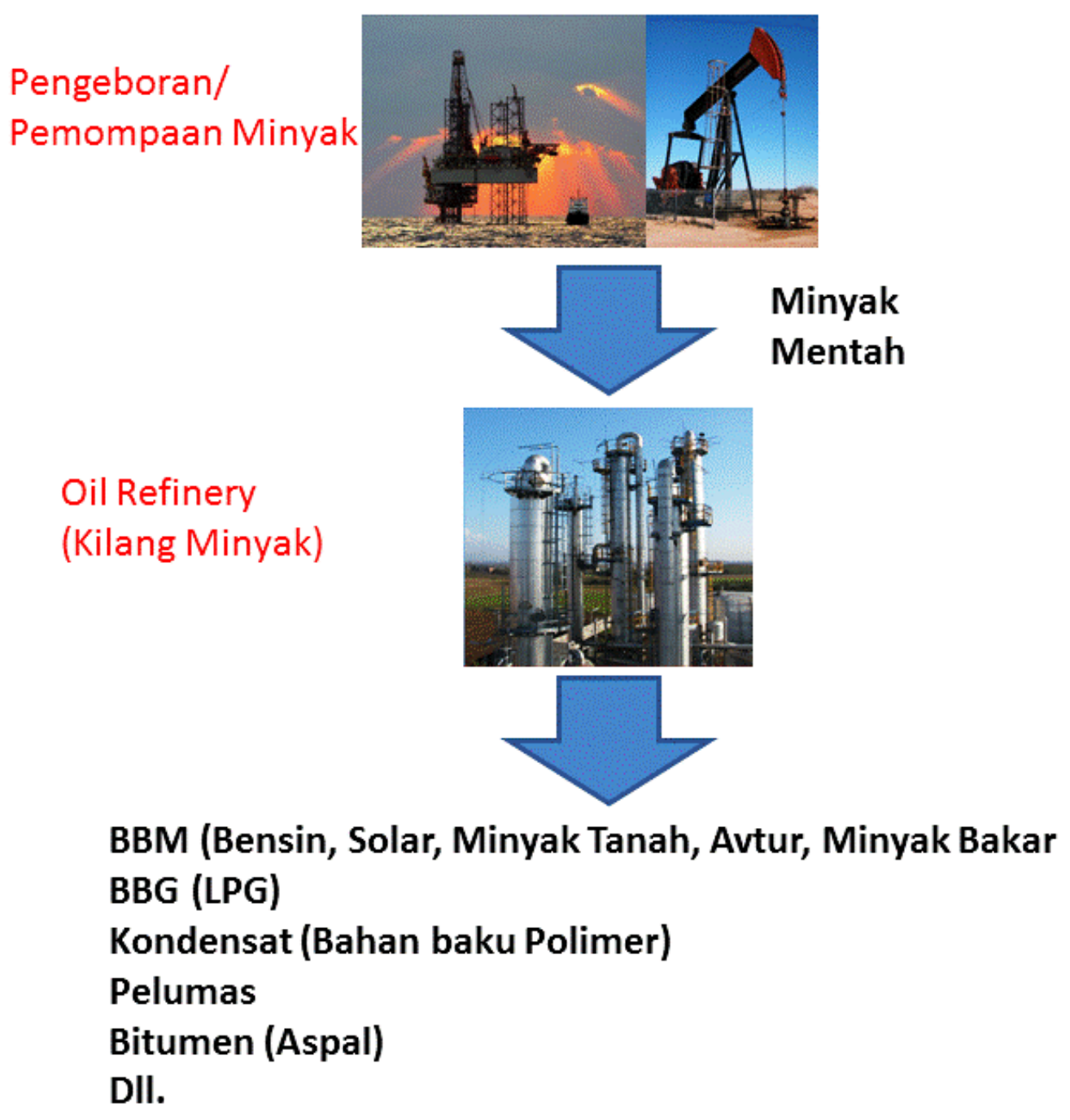




\section{PENGOLAHAN MINYAK BUMI SECARA UMUM}

Karena sifat-sfat minyak mentah sangat bervariasi dan jenis produk yang dapat dihasilkan juga sangat banyak, maka istilah kilang minyak tidaklah memberikan gambaran yang jelas mengenai operasi-operasi yang dilakukan dalam suatu kilang minyak.

Suatu operasi yang pasti dijumpai dalam kilang minyak, adalah Distilasi, yang mana memisahkan minyak bumi dengan ke dalam fraksi-fraksinya berdasarkan daerah (range) didihnya. Operasi lainnya, bisa saja sedikit atau banyaknya operasi yang dipergunakan atau prosesnya sederhana atau kompleks, tergantung kepada produk-produk yang akan dibuat atau dihasilkan.

Oleh karena itu, dapatlah dikatakan bahwa tidak ada dua buah kilang minyak yang mempunyai skema proses pengolahan yang sama. Semakin kompleks kilang minyak atau semakin beragam unit yang terdapat dalam kilang, maka semakin fleksibel-lah kilang tersebut, karena produk yang tidak dapat dipasarkan (produk/hasil samping) dapat diubah ke dalam produk yang dapat dipasarkan.

Suatu cara yang paling sederhana untuk memisahkan minyak mentah ke dalam fraksifraksinya adalah distilasi. Sifat-sifat fraksi tergantung pada komposisi minyak mentah dan tipe atau jenis produk "jadi" yang diinginkan. Minyak mentah mengandung senyawasenyawa hidrokarbon yang tidak semuanya cocok untuk semua produk yang diinginkan.

Adapun gambar fraksi-fraksi yang biasanya dapat diperoleh dari minyak mentah, daerah (range) didihnya, dan penggunaannya, adalah sebagai berikut : 
Gambar. 3 - 3, Distilah Minyak Mentah

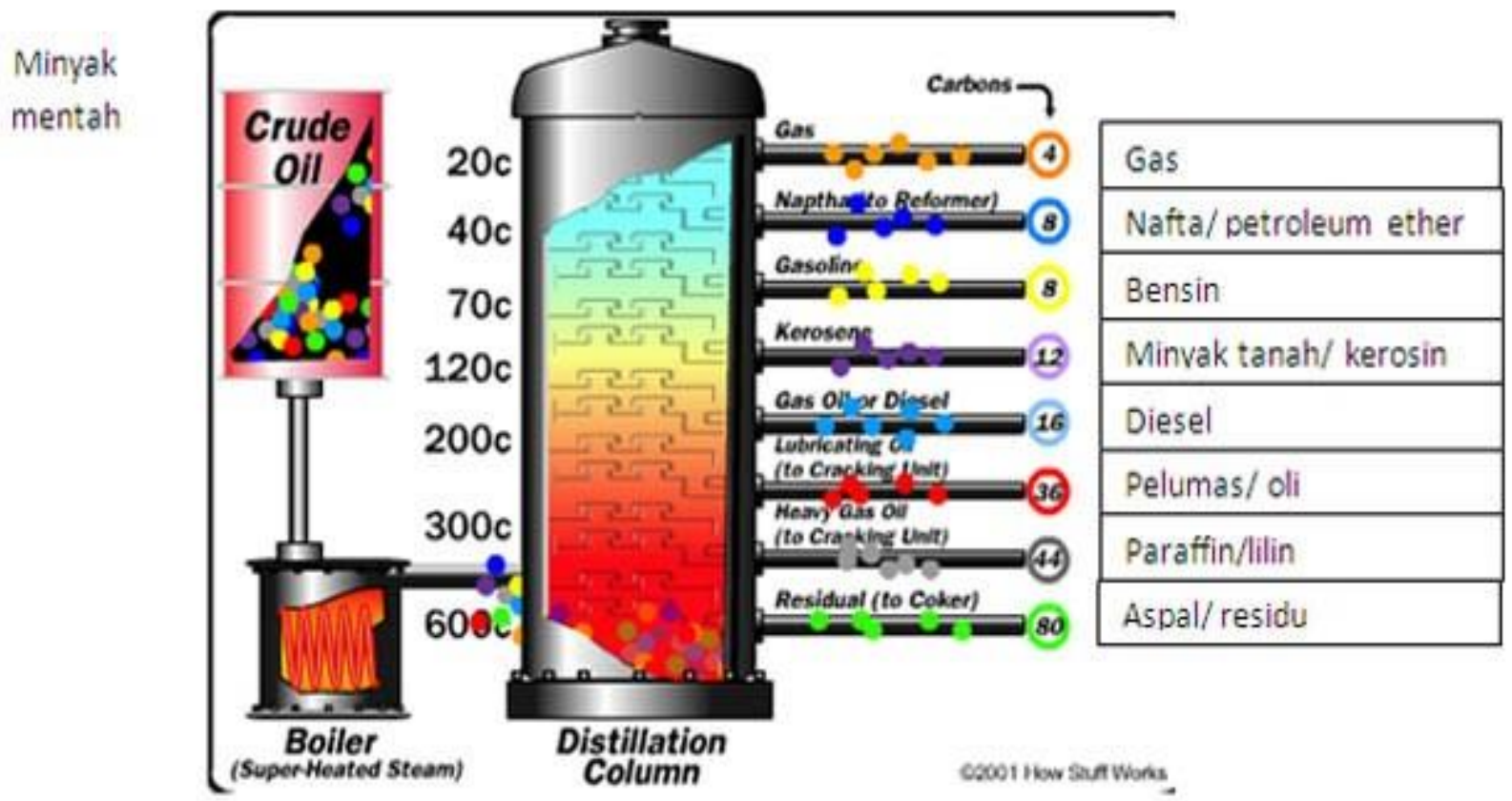

Bahan Bakar Gas

Propan

Butan

Nafta Ringan

Nafta Berat

Kerosin

Minyak Tungku

Minyak Gas Ringan
-259 sampai $-44^{\circ} \mathrm{F}$

$-44^{\circ} F$

$31^{\circ} \mathrm{F}$

30 sampai $300{ }^{\circ} \mathrm{F}$

300 sampai $400{ }^{\circ} \mathrm{F}$

400 sampai $500{ }^{\circ} \mathrm{F}$

400 sampai $550{ }^{\circ} \mathrm{F}$

400 sampai $600^{\circ} \mathrm{F}$
Metan, etan, dan sedikit propan. Untuk bahan bakar kilang.

\section{Elpiji}

Dicampur dengan bensin untuk Menaikkan volalitas bensin.

Komponen bensin motor.

Umpan reformer katalitik. Dicampur minyak gas ringan untuk membuat bahan bakar jet.

Bahan bakar kerosin

sama dengan kerosin, tetapi Dengan titik didih akhir yang Lebih tinggi.

Untuk bahan bakar dapur dan Bahan bakar diesel. Dapat pula dicampur dengan minyak tungku untuk menurunkan titik tuang. 
Minyak Gas Berat

600 sampai $800^{\circ} \mathrm{F}$

Minyak Gas Hampa

Residu Pendek
800 sampai $1100{ }^{\circ} \mathrm{F}$

$>1100^{\circ} \mathrm{F}$
Dapat dicampur dengan minyak gas hampa sebagai umpan untuk rengkahan katalitis.

Umpan untuk unit rengkahan Katalitis.

Untuk minyak bakar berat. Dapat dibuat aspal.

Gambar. 3 - 4. Distilation UIL
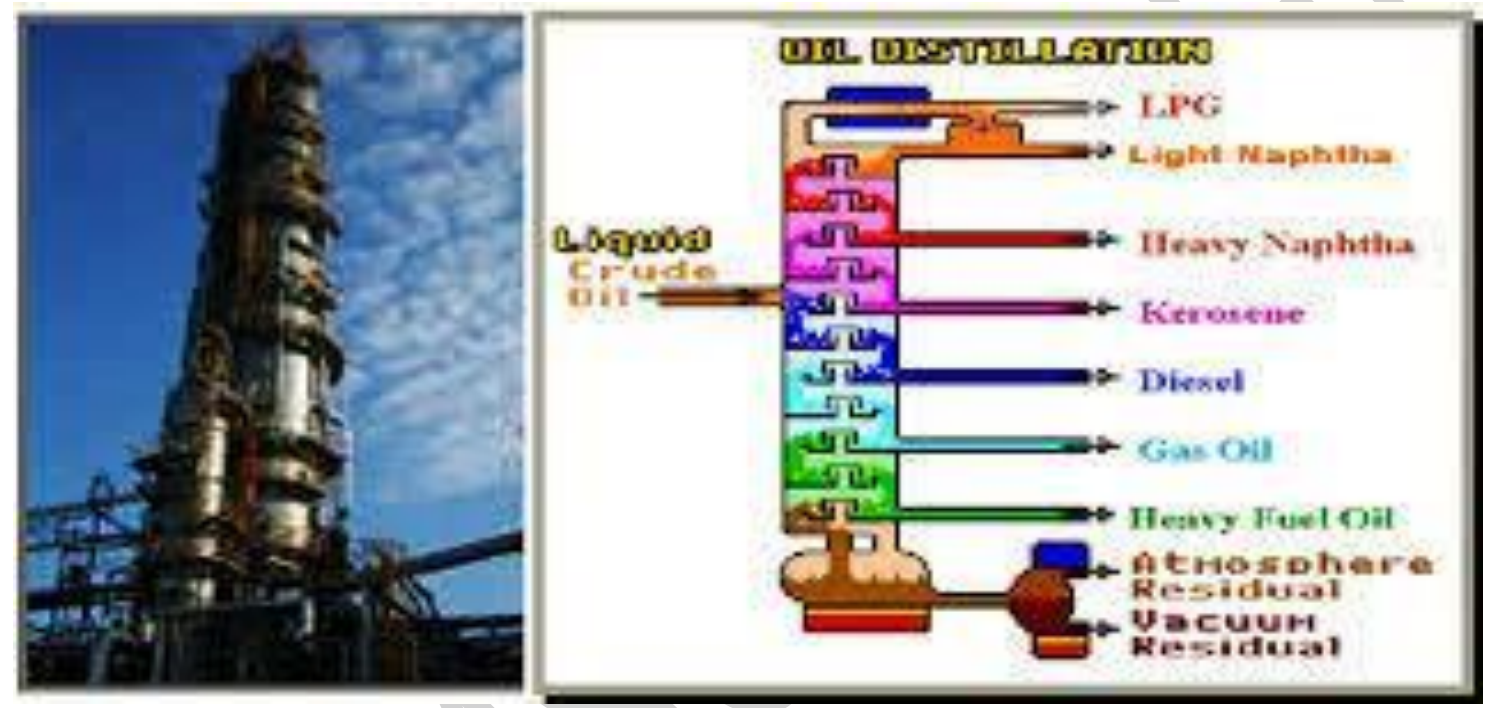

Kerosin, minyak tungku, dan minyak gas ringan, disebut Distilasi Tengahan.

Fraksi

- fraksi hingga gas berat diperoleh dengan cara Distilasi pada tekanan standar, sedangkan minyak gas hampa dan residu pendek diperoleh dengan jalan Distilasi hampa.

Umumnya tidak ada fraksi - fraksi atau gabungan fraksi - fraksi yang diperoleh dari proses pemisahan minyak mentah begitu saja, masing-masing harus mengalami perlakuan (treating) lebih lanjut yang berbeda-beda tergantung pada kotoran - kotoran yang terdalam dalam fraksi dan sifat-sifat yang diinginkan dalam produk "jadi". Perlakuan yang sangat sederhana terhadap fraksi, adalah pencucian soda untuk menghilangkan senyawa belerang, sedangkan serangkaian perlakuan yang kompleks adalah perlakuan pelarut (solvent treating), pengawalaman dengan pelarut (solvent dewaxing), perlakuan lempung (clay treating), dan perlakuan hydro (hidrotreating), serta percampuran (blending) untuk menghasilkan misalnya minyak pelumas. 
Diantara proses-proses yang kompleks, adalah proses-proses yang berhubungan dengan pembuatan bensin motor. Dalam minyak mentah, hanya ada sedikit komponen yang cocok untuk dibuat bensin motor modern., sehingga kilang minyak harus mempunyai unit-unit yang mengubah faksi-fraksi menjadi komponen bensin motor yang baik, diantaranya adalah unit reforming dan unit rengkahan katalitis. Unit reforming katalitis akan mengubah nafta berat yang memiliki angka oktan rendah menjadi nafta berat yang memiliki angka oktan tinggi. Sedangkan unit rengkahan katalitis akan mengubah fraksi minyak gas menjadi bensin motor dengan angka oktan tinggi. Unit rengkahan katalitis akan menghasilkan gas yang kaya akan olefin, yang selanjutnya dapat dipolimerisasi dalam unit polimerisasi katalitis menjadi bensin polimer.

Bagaimana minyak mentah diubah menjadi berbagai macam produk, dapat kami tunjukkan diagram alir di bawah. Perlu diketahui, bahwa "Tidak Ada Skema Proses" yang berlaku umum untuk semua kilang minyak, karena "Tidak Ada" kilang minyak yang mempunyai skema proses pengolahan yang sama.

\section{Gambar. 3 - 5. Diagram Alir Crude Oil Distilation}

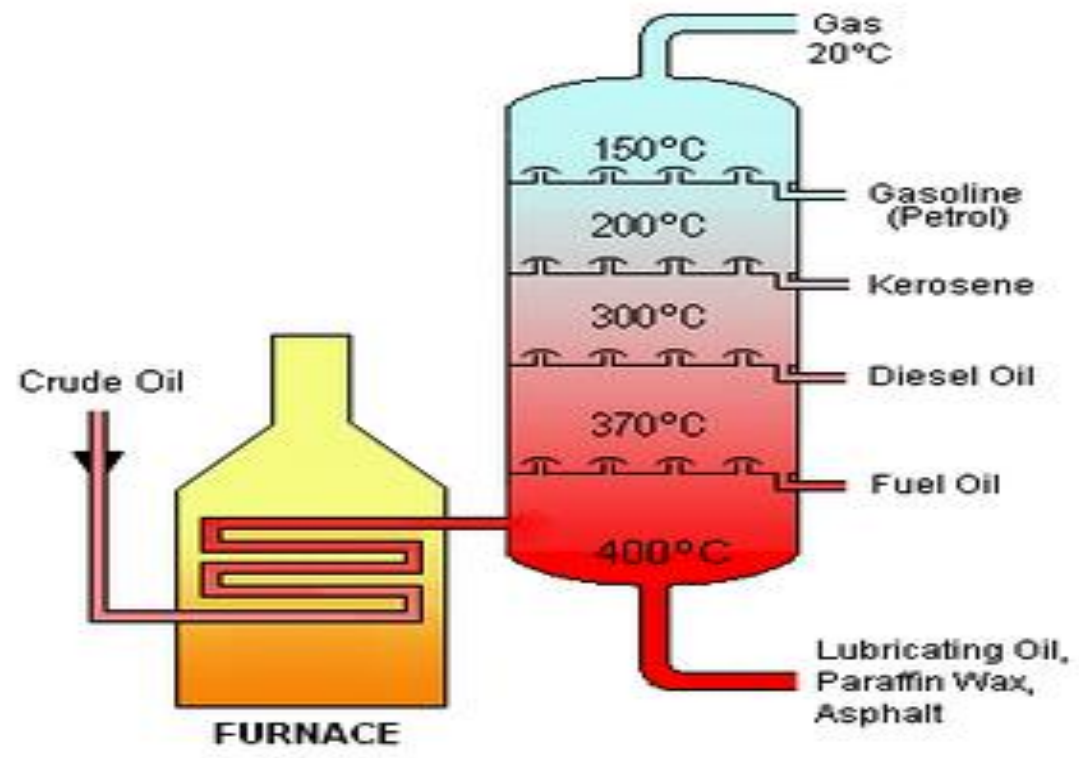


Gambar. 3-6. Diagram Alir Sebuah Kilang Minyak (Diagram Alir Sederhana Distilasi Atmosferik)

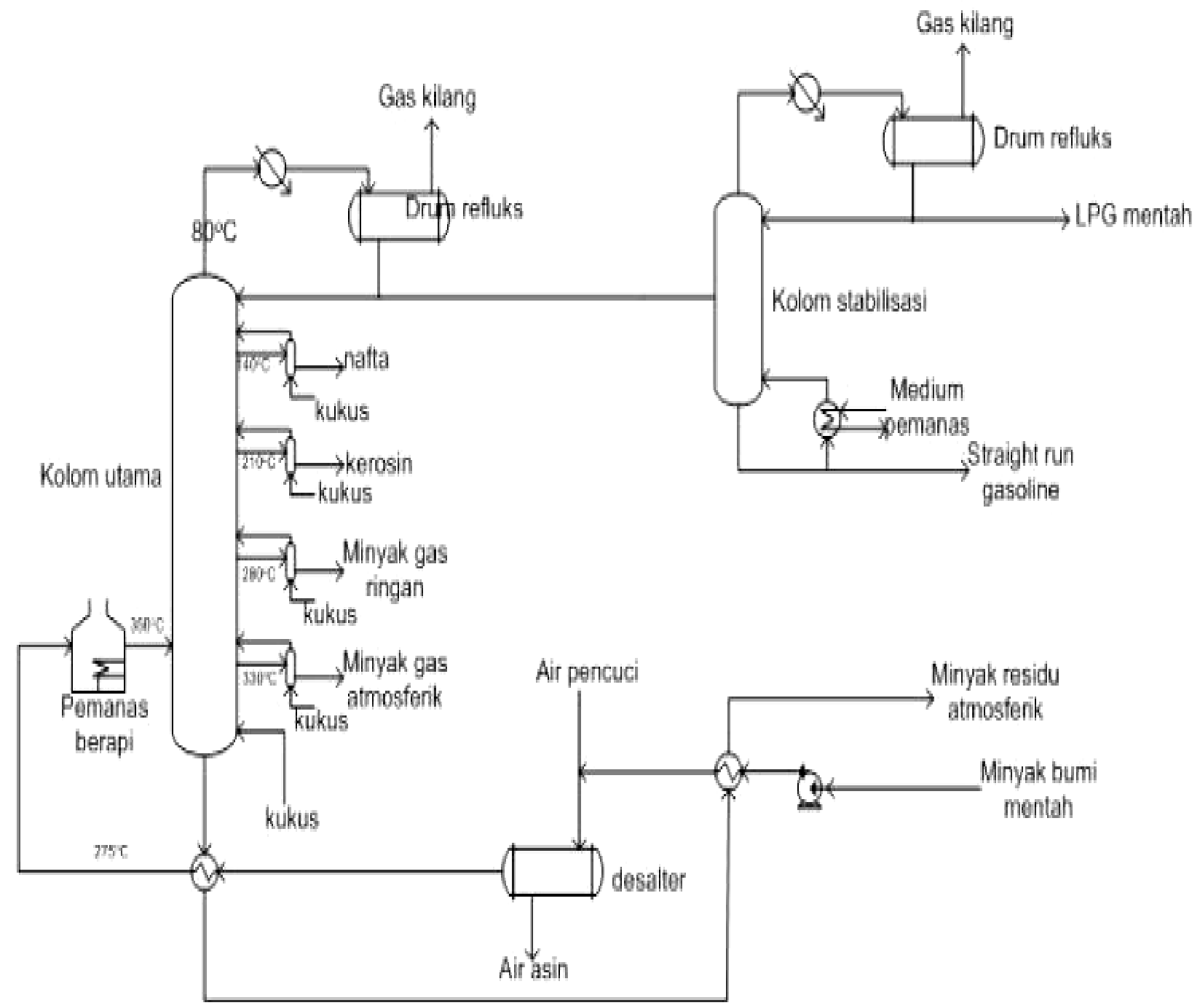


Gambar. 3 - 7, Diagram Alir Sebuah Kilang Minyak

(Diagram Alir Kilang Minyak Tipe Skimming)

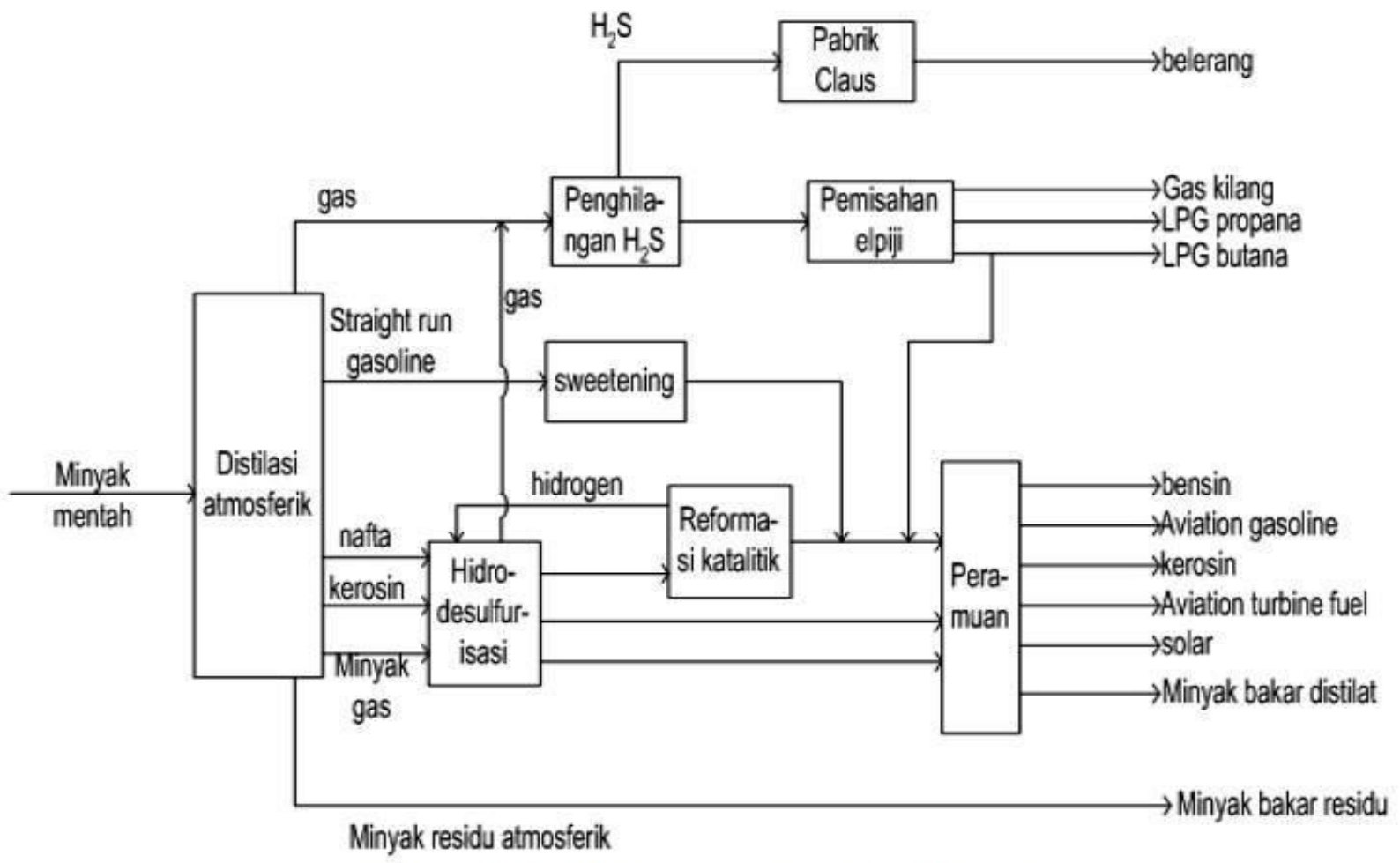

Di samping instalasi pengolahan yang lengkap, kilang minyak juga mempuyai fasilitas tangki-tangki untuk menyimpanan minyak mentah, produk "antara" dan produk "jadi", yaitu :

- Fasilitas penunjang yang menyediakan berbagai jenis air, uap air, tenaga listrik, dan udara instrument,

- Fasilitas bengkel,

- Fasilitas gudang untuk suku cadang,

- Fasilitas untuk penanganan limbah, dan

- Fasilitas pencampuran produk. 


\section{PRAPERLAKUAN MINYAK MENTAH}

Pada pengolahan minyak bumi dalam kilang minyak, unit distilasi atmosferis minyak mentah pada umumnya dapat dipandang sebagai Pintu Gerbangnya. Namun demikian, karena minyak mentah selalu terkotori oleh air garam yang berasal dari sumur, sehingga air garam ini perlu dihilangkan.

Minyak mentah yang berasal dari ladang minyak, dapat mengundang sejumlah besar garam, maksimumnya berkisar hingga $0,1 \%$ berat atau sekitar $300 \mathrm{lb} / 1000$ barel minyak mentah. Apabila garam ini tidak dihilangkan atau kandungannya diturunkan hingga batas-batas yang diperkenankan (sekitar $5 \mathrm{lb} / 1000$ barel minyak mentah), maka peralatan pengolahan yang terbuat dari baja dapat mengalami korosi. Sedangkan garam khlorid, khususnya magnesium khlorid akan mengalami hidrolisis jika menerima panas dan menghasilkan hydrogen khlorida bebas yang jika bereaksi dengan air akan membentuk asam khlorid yang korosif, menurut reaksi,

\section{$\mathrm{MgCl}_{2}+\mathrm{H}_{2} \mathrm{O} \rightarrow \mathrm{Mg}(\mathrm{OH}) \mathrm{Cl}+\mathrm{HCl}$}

Adapun air garam yang tersuspensi dalam minyak mentah dalam bentuk emulsi, maka emulsi dapat dipecah (diurai) dengan menggunakan bahan -bahan seperti, sabun, asam lemak, sulfonat, dan alkohol dengan rantai yang panjang.

Apabila digunakan bahan kimia sebagai pemecah emulsi, maka bahan kimia ini dapat ditambahkan pada sebuah tempat atau lebih dari tiga buah tempat dalam sistem, yaitu :

- Pada minyak mentah sebelum dicampur dengan air.

- Pada air sebelum dicampur dengan minyak mentah.

- Pada campuran minyak mentah dan air.

Akhirnya, dengan penggunaan medan listrik dengan tegangan tinggi (sekitar 16,500 33,000 ) volt dalam bejana pengendap, akan mempercepat penggabungan dan pengendapan air garam. 


\section{PROSES PENGOLAHAN MINYAK BUMI}

\section{DISTILASI (FRAKSINASI)}

(Sumber : "Refinery di Indonesia", by Risdiyanto, ST, MT)

Proses penyulingan berdasarkan perbedaan titik didih. Proses ini berlangsung di kolom distilasi atmosferik dan distilasi vakum.

Proses distilasi biasanya dialkukan pada sebuah tanur tinggi yang kedap udara. Minyak bumi mentah dialirkan ke dalamnya untuk dipanaskan dalam tekanan 1 atm pada suhu $370{ }^{\circ} \mathrm{C}$. Pemanasan ini menyebabkan fraksi-fraksi minyak bumi terpisah. Fraksi yang memiliki titik didih terendah akan berada di bagian atas tanur, sedangkan fraksi yang memiliki titik didih tinggi akan berada di dasar tanur.

\section{PROSES PRIMER DISTILASI ATMOSFIR (CDU)}

Crude Distilasi unit (CDU), beroperasi dengan prinsip dasar pemisahan berdasarkan titik didih komponen penyusunnya. Kolom CDU memproduksi produk LPG, Naphta, Kerosin (Minyak Tanah), dan Diesel sebesar 50-60\% volum umpan, sedangkan produk lainnya sebesar $40-50 \%$ volum umpan dengan berupa atmosfir residu, yang berfungsi untuk memisahkan minyak mentah atas fraksi-fraksinya pada keadaan atmosfir.

Pada kilang modern, atmosferic residu dikirim sebagai umpan Vacum Distilation Unit untuk menghilangkan kandungan metal atmospheric residu.

Berikut gambar proses distilasi atmosferis.

Gambar. 3- 8 Proses Distilasi Atmosferis. 


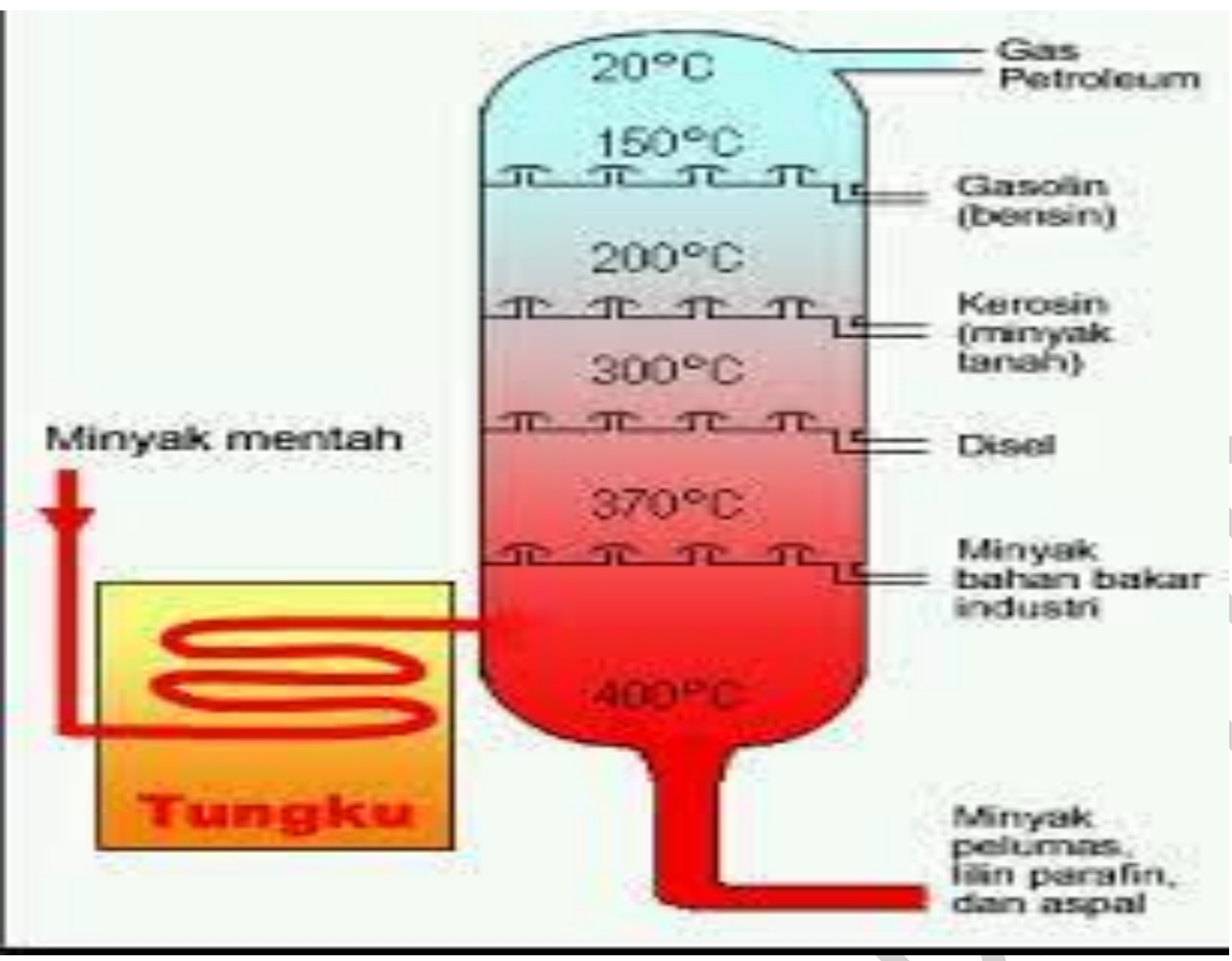

Gambar. 3- 9. Kolom Fraksinasi.

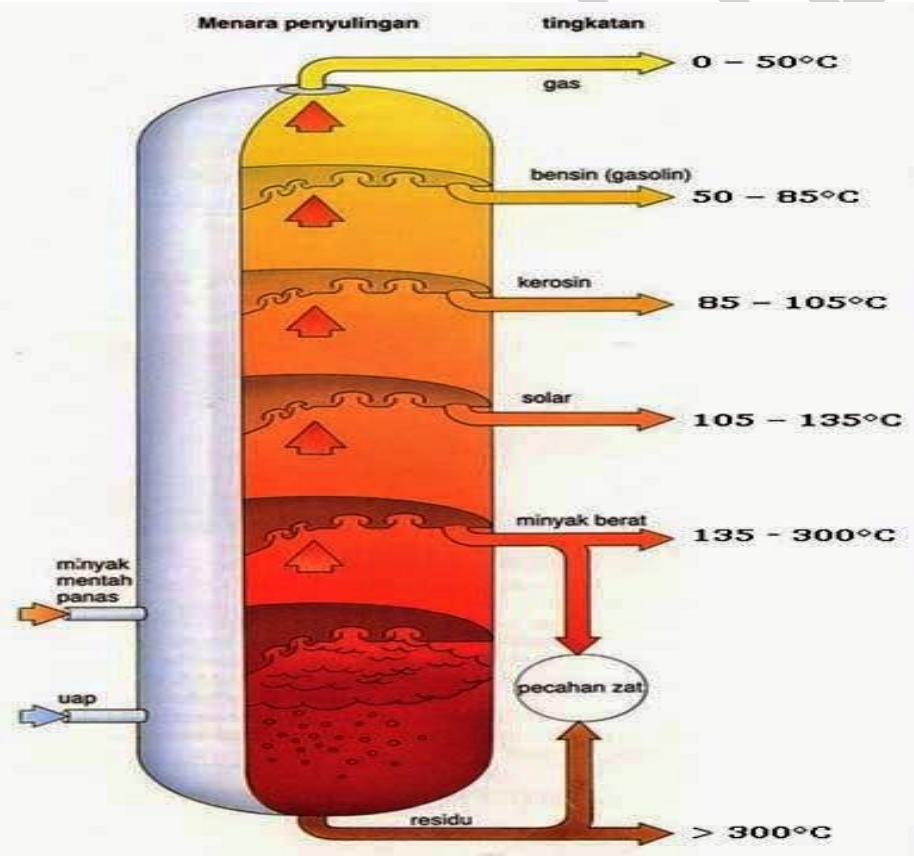

\begin{tabular}{|c|}
\hline $\begin{array}{l}\text { gas tabung } \\
\text { bahan kimia }\end{array}$ \\
\hline $\begin{array}{l}\text { bahan bakar mobil } \\
\text { plastik kimia } \\
\text { bahan kima }\end{array}$ \\
\hline $\begin{array}{l}\text { bahan bakar jet } \\
\text { bahan bakar pernanas } \\
\text { parafin }\end{array}$ \\
\hline $\begin{array}{l}\text { bahan bakar truk dan bus } \\
\text { bahan bakar pemanasan } \\
\text { sentral }\end{array}$ \\
\hline minyak pelumas \\
\hline $\begin{array}{l}\text { lilin, } \\
\text { pelapis lilin } \\
\text { permoles } \\
\text { bahan kimia }\end{array}$ \\
\hline $\begin{array}{l}\text { bahan bakar pembangkit } \\
\text { tenaga }\end{array}$ \\
\hline $\begin{array}{l}\text { proses penguraian aspal } \\
\text { untuk permulkaan jalan } \\
\text { dan membuat atap }\end{array}$ \\
\hline \\
\hline
\end{tabular}

\section{CRACKING}


Cracking, adalah tahapan pengolahan minyak bumi yang dilakukan untuk menguraikan molekul-molekul besar senyawa hidrokarbon menjadi molekul-molekul hidrokarbon yang lebih kecil, misalnya pengolahan fraksi minyak solar atau minyak tanah menjadi bensin. Fraksi-fraksi yang dihasilkan dari proses distilasi di atas, kemudian dimurnikan (refinery) melalui proses Cracking.

Proses cracking, dapat dilakukan dengan 3 cara, yaitu cara panas (thermal cracking), cara katalis (catalytic cracjking), dan hidrocracking.

\section{REFORMING}

Setelah dilakukan pemurnian melalui cracking, tahap pengolahan minyak bumi dilanjut dengan proses reforming. Reforming adalah proses merubah struktur molekul fraksi yang mutunya buruk (rantai karbon lurus) menjadi fraksi yang mutunya lebih baik (rantai karbon bercabang) yang dilakukan dengan penggunaan katalis atau proses pemanasan. Karena dilakukan untuk merubah struktur molekul, maka proses ini juga bisa disebut sebagai proses isomerisasi.

\section{ALKILASI DAN POLIMERISASI}

Setelah diperbaiki struktur molekulnya, fraksi-fraksi yang dihasilkan dari pengolahan minyak bumi mentah kemudian melalui proses alkilasi dan polimerisasi.

Alkilasi adalah tahap penambahan jumlah atom pada fraksi sehingga molekul fraksi menjadi yang lebih panjang dan bercabang. Proses alkilasi menggunakan penambahan katalis asam kuat seperti $\mathrm{HCl}_{2} \mathrm{H}_{2} \mathrm{SO}_{4}$, atau $\mathrm{AlCl}_{3}$ (suatu asam kuat lewis)

Sedangkan polimerisasi adalah tahap penggabungan molekul-molekul kecil menjadi molekul yang lebih besar dalam fraksi sehingga mutu dari produk akhir akan lebih meningkat.

Gambar. 3 - 10. Polimer Flowchart 


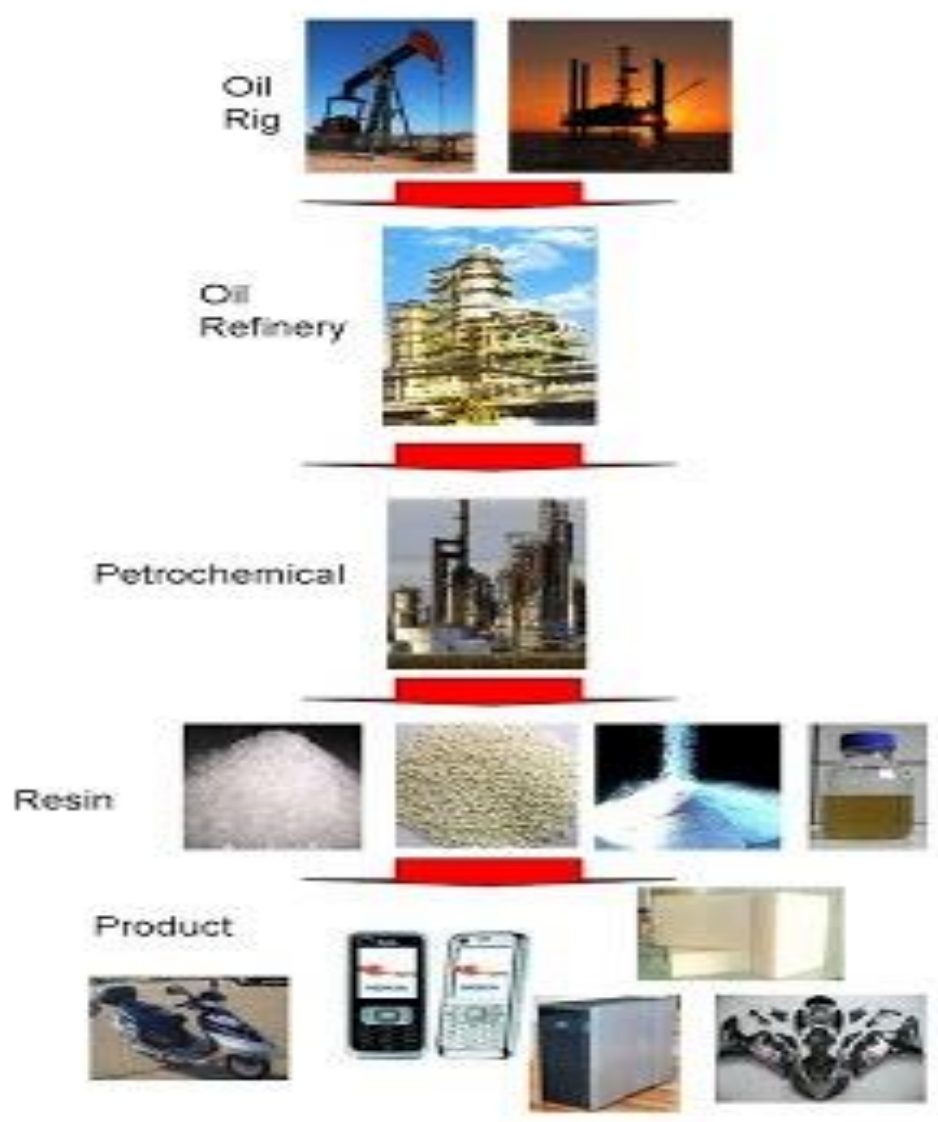

\section{TREATING}

Treating adalah proses pemurnian fraksi minyak bumi melalui eliminasi bahan-bahan pengotor yang terikut dalam proses pengolahan atau yang berasal dari bahan baku minyak mentah. Bahan-bahan pengotor yang dihilangkan dalam proses treating tersebut antara lain bau tidak sedap melalui copper sweetening dan doctor treating, lumpur dan warna melalui acid treatment, parafin melalui dewaxing, aspal melalui deasphalting, dan belerang melalui desulfurizin.

\section{BLENDING}


Tahap terakhir yang dilalui dalam proses pengolahan minyak bumi sehingga menghasilkan bahan siap guna adalah proses blending.

Blending adalah tahapan yang dilakukan untuk meningkatkan kualitas produk melalui penambahan bahan-bahan aditif ke dalam fraksi minyak bumi. Bahan-bahan aditif yang digunakan tersebut salah satunya adalah tetra ethyl lead (TEL).

TEL adalah bahan aditif yang digunakan menaikkan bilangan oktan bensin.

\section{PRODUK MINYAK BUMI}

\section{ELPIJI}

Elpiji (LPG - Liquified Petroleum Gases),, adalah gas minyak bumi yang dicairkan pada suhu biasa dan tekanan sedang, sehingga elpiji dapat disimpan dan diangkut dalam bentuk cair dalam bejana yang bertekanan tertentu.

Komponen utama elpiji, adalah Propan dan Butan. Selain itu, terdapat pula Etan dan Pentan dalam jumlah yang sangat kecil dan terbatas. Adapula sejumlah kecil belerang yang sengaja ditambahkan dalam bentuk senyawa merkaptan, etil atau butil merkaptan, yang berfungsi untuk mengetahui ada atau tidak adanya kebocoran gas.

Elpiji mempunyai 4 (empat) type (ASTM D 1835 - 89), yaitu :

- Elpiji - Propan

- Elpiji-Butan

- Elpiji campuran Propan - Butan

- Elpiji Propan Spesifik atau Khusus (Special Duty Propane).

Khusus Indonesia, memproduksi 3 (tiga) jenis elpiji, yaitu Elpiji Campuran, Elpiji Propan, dan Elpiji Butan, yang tiap - tiap spesifikasinya dapat dilihat pada lampiran 2, 3, dan 4.

Adapun manfaat elpiji, adalah sebagai berikut, 
$\checkmark \quad$ Sebagai bahan bakar dalam rumah tangga dan industri.

$\checkmark \quad$ Sebagai bahan bakar mesin motor bakar. Karena Propan mempunyai angka oktan yang tinggi yaitu 97, maka penggunaan bahan bakar yang ekonomis harus digunakan dalam mesin motor bakar dengan kompresi yang tinggi, yaitu $10: 1$.

$\checkmark \quad$ Sebagai bahan baku industri petrokimia.

$\checkmark \quad$ Sebagai pengganti bensin, dalam kendaraan bermotor.

\section{BENSIN MOTOR}

Bensin motor, adalah campuran kompleks yang utamanya terdiri dari senyawa-senyawa hidrokarbon, yang memiliki daerah (range) didih ASTM sekitar $30-150{ }^{\circ} \mathrm{C}$, dan digunakan sebagai bahan bakar mesin motor.

Kilang minyak di Indonesia, memproduksi minyak 5 (lima) jenis bensin motor, yaitu :

$>\quad$ Bensin Premium 88,

- Angka oktan riset minimum 88,

- Berwarna kuning, dan

- Menggunakan pengangkat oktan TEL, maksimum 1,5 mL / Galon Amerika bensin.

$>\quad$ Bensin Premix 94 (Pertalite),

- Angka oktan riset minimum 94,

- Berwarna Orange,

- Menggunakan pengangkat oktan TEL, dengan kandungan maksimum $\mathrm{Pb}$ 0,45 gram / L, dan kandungan maksimum MTBE (metal tersier butil eter) $15 \%$ volum.

$>\quad$ Bensin Super 95 (Pertamax),

- Angka oktan riset minimum 95,

- Tidak berwarna,

- Tidak mengandung TEL,

- Dapat ditambahkan MTBE maksimum $10 \%$ volum, untuk memenuhi spesifikasi angka oktan.

$>\quad$ Bensin Prima 98 (Pertamax Plus), 
- Angka oktan riset minimum 98,

- Tidak berwarna,

- Tidak mengandung TEL,

- Dapat ditambahkan MTBE maksimum $15 \%$ volum, untuk memenuhi spesifikasi angka oktan.

$>\quad$ Bensin Petro 2T,

- Angka oktan riset minimum 72 ,

- Berwarna hijau,

- Kandungan timbal $(\mathrm{Pb})$ maksimum 0,1 gram / L,

- Dapat ditambahkan MTBE maksimum $15 \%$ volum, untuk memenuhi spesifikasi angka oktan.

- Bensin ini khusus untuk mesin motor bakar dua tahap (2 langkah).

\subsection{SIFAT BENSIN MOTOR}

Sifat penting yang dibutuhkan, adalah volalitas dan karakteristik anti ketukan (anti knock characteristics).

\section{$\underline{\text { Volalitas }}$}

Volalitas bensin yang dapat ditentukan dengan uji tekanan uap Reid (ASTM D 323) dan distilasi ASTM (ASTM D 86), berpengaruh terhadap kemudahan mesin dihidupkan dalam keadaan dingin, pemanasan, percepatan, daya, dan ekonomis pada penggunaan bensin pada kondisi mesin apapun.

\section{Sifat Anti Ketuk (Anti Knock)}


Setiap bensin mempunyai kemampuan tertentu dalam melakukan sejumlah kerja yang maksimum. Jika bensin digunakan untuk melakukan kerja melampaui maksimum kerjanya, maka bensin akan memberikan suara ketukan dalam mesin (engine knock). Jika bensin dibakar relatif lambat, maka bensin dapat memberikan daya maksimum.

Pada kondisi ini, tersedia waktu yang cukup bagi tekanan untuk disalurkan ke torak dan memberikan dorongan yang kuat. Tetapi jika mesin dipercepat atau mesin dipaksa bekerja keras, maka bensin tidak terbakar seperti biasa, sehingga akan meledak. Ledakan atau pembakaran bensin yang sangat cepat mengakibatkan mesin mengetuk. Jika ketukan mesin terjadi, maka kenaikan tekanan semakin cepat yang disebabkan pelepasan panas, sehingga kenaikan tekanan akan dihilangkan untuk melawan kelembaban torak.

Bensin mempunyai kemampuan yang berbeda-beda dalam menahan ketukan. Tahanan ketukan bensin, disebut Kualitas anti ketuk (anti knock quality) dan diukur dengan angka oktan. Makin tinggi kualitas anti ketuk, makin tinggi pula kemampuan bensin untuk menahan ketukan dan makin besar pula daya maksimum yang dapat dihasilkan.

Perlu diketahui, bahwa bensin dengan kualitas anti ketuk yang tinggi hanya diperlukan pada waktu mesin harus memberikan daya yang tinggi, seperti pada saat ada percepatan. Pada saat mengendarai kendaraan dengan kondisi yang tetap (konstan) dan pada jalanan yang datar, bensin dengan angka oktan rendah dapat menjalankan mesin tanpa ada ketukan.

\subsection{PENGANGKAT ANGKA OKTAN}

Untuk mendapatkan bensin dengan angka oktan yang tinggi sesuai dengan spesifikasin pemasarannya, maka bensin perlu ditambahkan pengangkat oktan (octane boaster).

Pengangkat oktan yang sering digunakan pada masa lampau, adalah TEL (tetra etil lead), dan $\mathrm{Pb}\left(\mathrm{C}_{2} \mathrm{H}_{5}\right)_{4}$. Karena TEL sangat beracun dan masyarakat sadar akan pencemaran udara (lingungan), maka TEL tidak lagi dipergunakan.

\section{BENSIN PENERBANGAN}


Bensin penerbangan, adalah campuran senyawa hodrokarbon yang memiliki daerah (range) didih sekitar $35-170{ }^{\circ} \mathrm{C}$, dan digunakan sebagai bahan bakae mesin pesawat terbang.

Menurut ASTM, terdapat tiga macam grade bensin penerbangan (ASTM D $910-90$ ), yaitu bensin penerbangan,

$\begin{array}{lll}\text { - } & \text { Grade } 80, & \text { Warna Merah } \\ \text { - } & \text { Grade } 100, & \text { Warna Hijau } \\ \text { - Grade } 100 \text { LL, } & \text { Warna Biru }\end{array}$

Bensin penerbangan grade 100 dan grade $100 \mathrm{LL}$ mempunyai angka oktan yang sama, perbedaannya adalah pada kandungan TEL. Grade 100 LL, kandungan TELnya lebih rendah dibangdingkan grade 100.

Indonesia hanya memproduksi bensin penerbangan 73 , sedangkan bensin penerbangan 100/130 yang pernah diproduksi, sekarang tidak diproduksi lagi. Sebagai konsumen bensin penerbangan tersbesar di Indonesia, adalah angkatan perang, walaupun pemakaiannya tidak banyak lagi. Di luar negeri, bensin penerbangan grade 73 sudah tidak diproduksi lagi, demikian juga grade 100/130, sebab sebagian besar negara-negara di dunia telah mengembangkan bensin grade baru, yaitu grade $100 \mathrm{LL}$ yang berwawasan lingkungan.

\section{BAHAN BAKAR TURBIN PENERBANGAN}

Bahan bakar turbin penerbangan (aviation turbine fuel, avtur) atau bahan bakar jet (jet fuel), adalah campuran senyawa hidrokarbon yang digunakan sebagai bahan bakar mesin turbin atau mesin jet penerbangan.

Mesin jet penerbangan, bekerja dari suhu kamar hingga suhu yang sangat rendah $70^{\circ} \mathrm{C}\left(-90^{\circ} \mathrm{F}\right)$, sehingga fraksi solar tidak dapat digunakan karena bahan bakar ini akan membeku pada suhu yang rendah. Fraksi ringan seperti bensin, juga tidak dapat digunakan karena pada tekanan yang sangat rendah (sekitar 1/10 tekanan di atas tanah) fraksi ini akan mendidih dan habis menguap. Ternyata, bahwa bahan bakar yang paling cocok untuk mesin jet adalah fraksi kerosin, karena fraksi kerosin yang dihasilkan kilang jumlahnya tidak mencukupi, maka selain fraksi kerosin, dalam bahan bakar jet juga diikutsertakan fraksi bensin dan fraksi minyak gas rengkahan yang mendidih dalam daerah didih kerosin (kerosin rengkahan).

\subsection{SPESIFIKASI BAHAN BAKAR JET}


Ada beberapa macam spesifikasi bahan bakar jet di dunia, yaitu spesifikasi menurut Angkatan Perang Amerika Serikat, ASTM, Inggris Raya (Great Britain) dan IATA (International Air Transport Association).

Menurut spesifikasi Angkatan Perang Amerika Serikat, ada 6 jenis bahan bakar jet, yaitu :
- JP - 1,
- $\mathrm{JP}-2$,
Kerosin penerbangan,
- $\mathrm{JP}-3$,
Bensin penerbangan, sekarang tidak diproduksi lagi,
- $\mathrm{JP}-4$,
Campuran bensin dan kerosin, RVP $5-7$ psi,
- JP -5 , Campuran bensin dan kerosin, RVP $2-3$ psi, daerah didih $200-500{ }^{\circ} \mathrm{F}$,
- JP -6 Kerosin dengan titik nyala tinggi, daerah (range) titik didih $350-550^{\circ} \mathrm{F}$,
- JP - 6, Kerosin dengan daerah didih luas (wide cut kerosin), daerah didih $250-550^{\circ} \mathrm{F}$.

Diantara bahan bakar jet di atas, yang paling banyak digunakan adalah JP - 4 .

Menurut ASTM, bahan bakar jet dibagi menjadi 3 jenis (ASTM D $1655-90$ ), yaitu :

- Jet $A$, Menyerupai kerosin dengan titik nyala relative tinggi,

- Jet $A-1$, Serupa dengan jet $A$, berbeda dalam titik beku,

- Jet B, Distilat dengan daerah didih yang relative luas.

Bahan bakar Jet B, sangat sesuai dengan JP - 4, menurut spesifikasi angkatan perang amerika serikat.

Menurut Inggris raya, bahan bakar jet dibagi menjadi 2 jenis, yaitu :

- AVTAG (DERD 2486),

- AVTUR (DERD 2494),
Campuran kerosin dan bensin (wide cut), Tekanan uap Reid 2 - 3 psi, titik beku Maksimum $-58^{\circ} \mathrm{C}$.

Kerosin penerbangan, titik beku maksimum $-50^{\circ} \mathrm{C}$.

IATA membagi bahan bakar turbin penerbangan menjadi dua, yaitu : 
- Kerosin,

- Wide cut,
Kerosin penerbangan, titik beku maksimum $-50^{\circ} \mathrm{C}$.

Distilat dengan daerah (range) titik didih yang relatif luas.

Di Indonesia telah lama menggunakan bahan bakar jet avtur 50, yang sesuai dengan spesifikasi bahan bakar jet Inggris Raya avtur (DERD 2494).

\subsection{SIFAT - SIFAT BAHAN BAKAR JET}

Sifat - sifat bahan bakar jet yang penting, adalah sifat-sifat yang berhubungan dengan pembakaran bahan bakar (penyalaan, stabilitas nyala, deposit karbon, dII) dan penanganan bahan bakar (pemompaan, pengabutan, penyaringan, dII) terutama pada penerbangan yang tinggi.

Pada ketinggian yang rendah, suhu dan tekanan adalah sedemikian sehingga operasi mesin tidak banyak tergantung kepada sifat-sifat bahan bakar. Tetapi kandungan aromat perlu dibatasi sampai $25 \%$ untuk mengurangi pembentukan asap. Kecenderungan terbentuknya asap pada pembakaran senyawa akan menurun, menurut urutan sebagai berikut,

\section{Aromat-....... Naften-....... i-Parafin....... n-Parafin}

Di samping itu, suhu $90 \%$ teruapkan atau titik didih akhir (EP) distilasi ASTM perlu diatur agar pembakaran tidak cenderung membentuk karbon. Pembentukan karbon pada nozel sembur bahan bakar dapat mengubah bentuk nyala, mengakibatkan percampuran yang tidak baik antara bahan bakar dan udara serta pembakaran yang tidak baik. Pembentukan karbon pada dinding ruang pembakaran, dapat mengakibatkan terjadinya pemanasan setempat (hot spot) yang dapat merusak dinding.

\section{ZAT PELARUT}


Zat pelarut atau solven yang berasal dari minyak bumi terdiri dari campuran senyawa hidrokarbon parafi, naften, dan aromat. Zat pelarut yang terutama terdiri dari senyawa hidrokarbon aromat yang disebut zat pelarut aromatis. Sedamgkan yang utama dari campuran senyawa hidrokarbon parafin dan naften disebut zat pelarut alifatis. Zat pelarut alifatis diperoleh dari distilasi minyak mentah dan merupakan fraksi bensin, sehingga berbau bensin, sedangkan zat pelarut aromatis diperoleh dengan proses reforming. Zat pelarut aromatis juga dapat diperoleh dari industri batubara. Zat pelarut aromatis mempunyai bau yang kuat yang disebabkan oleh bau senyawa aromat.

Zat pelarut hidrokarbon pada umumnya stabil, yaitu zat pelarut umumnya tidak bereaksi dengan bahan-bahan, tidak terurai karena pemanasan yang sedang atau karena adanya air. Zat pelarut hidrokarbon tidak korosif terhadap logam.

Penggunaan zat pelarut,hidrokarbon, umumnya digunakan sebagai zat pelarut dan pengencer dalam pabrik cat, sebagai zat pelarut pada obat pembunuh serangga, sebagai zat pelarut untuk mengekstraksi lemak dan minyak nabati dan hewani, dan sebagai zat pelarut dalam industri karet.

\section{BAHAN BAKAR DIESEL}

Bahan bakar diesel, adalah fraksi minyak bumi yang mendidih sekitar $175-370{ }^{\circ} \mathrm{C}$ dan yang digunakan sebagai bahan bakar mesin diesel .

Mesin diesel ditemukan dan dipatenkan oleh Rudoph Diesel pada tahun 1892 - 1920, mesin diesel merupakan mesin stationer besar dengan dua hingga Sembilan torak, dengan diameter antara $25-50 \mathrm{~cm}$. dan dengan kecepatan maksimum $50-300$ putaran per menit. Mesin diesel telah disesuaikan sebagai alat transportasi.

Dewasa ini dijumpai mesin diesel dengan ukuran yang bermacam-macam, dan ukuran yang kecil hingga ukuran yang sangat besar untuk mesin diesel stasioner.

Berikut gambar tentang distribusi minyak (bahan bakar) diesel,

Gambar. 3 - 11. Distribusi Minyak Diesel. 


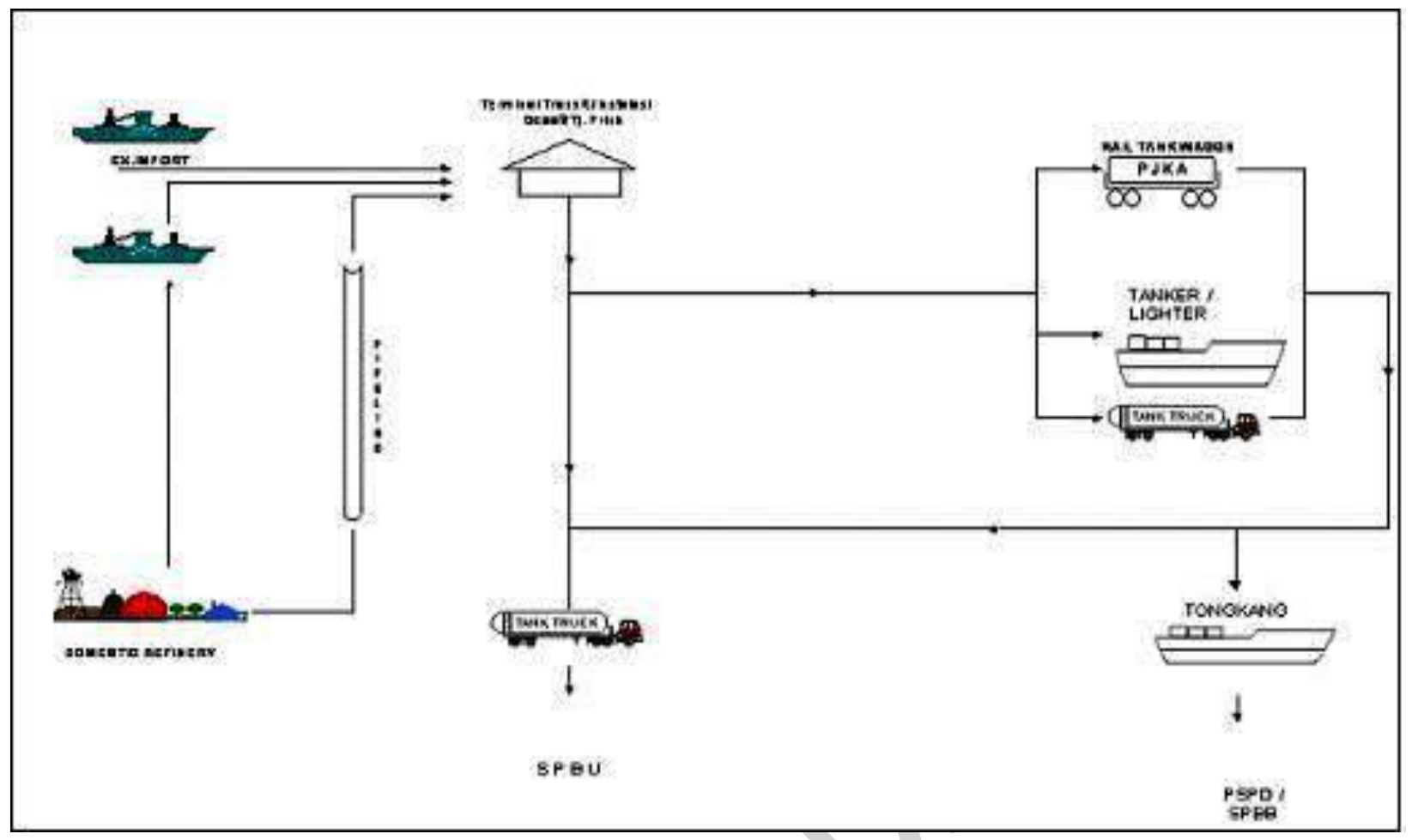

\section{MINYAK BAKAR}

Istilah minyak bakar dalam arti yang luas, adalah bahan bakar minyak yang dibakar untuk menghasilkan panas. Dengan pengertian ini, maka kerosin dapat juga digolongkan sebagai minyak bakar. Karena kerosin disamping sebagai bahan bakar untuk lampu penerangan, dapat juga digunakan sebagai bahan bakar yang menghasilkan panas dalam kompor yang digunakan dalam rumah tangga.

Maka dari itu, penjelasan tentang minyak bakar, lebih jelasnya akan kami kupas dalam pembahasan tentang kerosin (minyak tanah).

\section{MINYAK PELUMAS}


Minyak pelumas terdapat dalam bagian minyak mentah yang mempunyai daerah didih yang paling tinggi, yaitu sekitar lebih dari $400^{\circ} \mathrm{C}$.

Fraksi minyak pelumas dipisahkan dari residu hasil distilasi minyak mentah dengan distilasi hampa. Dalam distilasi ini, umumnya diperoleh 3 (tiga) fraksi, yaitu fraksi minyak pelumas ringan, fraksi minyak pelumas sedang, dan fraksi minyak pelumas berat. Karena aspal mempunyai daerah didih yang kira-kira sesuai dengan daerah didih minyak pelumas, maka dalam distilasi untuk memperoleh fraksi minyak pelumas selalu akan tercampur dengan aspal, tergantung pada jenis minyak mentahnya.

\section{$>\quad$ Komposisi Minyak Pelumas}

Minyak pelumas terdiri dari senyawa-senyawa hidrokarbon parafin, naften, aromat dan sejumlah kecil senyawa organic yang mengandung oksigen dan belerang yang dipandang sebagai pengotor.

Struktur utama molekul minyak pelumas adalah inti naften dan inti aromat, yang tersusun berkelompok hingga sebanyak enam cincin. Pada kelompok cincin ini dapat terikat rantai parafin. Makin panjang dan makin panjang rantai parafin ini, maka minyak pelumas makin bersifat parafin. Minyak pelumas naftenik, mengandung lebih banyak cincin aromat dan lebih sedikit rantai parafin. .

\section{$>\quad$ Fungsi Minyak Pelumas}

Fungsi utama minyak pelumas, adalah untuk memberikan lapisan minyak antara dua permukaan yang begeser satu terhadap yang lain, sehingga dapat mencegah terjadinya keausan dan memperkecil kehilangan daya. Selain itu, minyak pelumas juga harus dapat mengalir dengan bebas sehingga panas yang timbul karena gesekan dapat dihilangkan.

Dewasa ini, PERTAMINA telah memproduksi berbagai jenis minyak pelumas, yaitu minyak pelumas mesin motor empat langkah, baik yang berbahan bakar bensin maupun bahan bakar diesel, seperti mesran, mesran B, mesran prima, mesran super, meditran, meditran $S$, mendripal, mendripal $D$, dan lain-lain.

\section{ASPAL}

Aspal adalah bitumen setengah padat berwarna hitam yang berasal dari minyak bumi. Aspal terdiri dari partikel-pertikel koloid yang disebut aspalten yang terdispersi di dalam 
resin dan konstituen minyak. Perbandingan aspalten, resin, dan konstituen minyak tergantung dari minyak bumi asal dan cara pengolahannya.

Aspalten dapat dipisahkan dari resin dan konstituen minyak dengan jalan melarutkannya dalam nafta. Aspalten yang tidak larut akan mengendap sebagai serbuk yang berwarna coklat atau hitam. Diperkirakan aspalten terdiri dari gugus-gugus hidrokarbon, atom belerang, dan oksigen.

Minyak dapat dipisahkan dari resin dengan jalan adsorbs dengan bantuan lempung. Konstituen minyak adalah minyak pelumas yang mempunyai viskositas yang tinggi, berwarna coklat tua atau kemerah-merahan.

\subsection{Sifat - Sifat Aspal}

- $\quad$ Adhesi (lengket) dan Kohesi (melawan tarikan)

- Tahan terhadap air

- $\quad$ Sifat kimia yang stabil

- $\quad$ Tidak terpengaruh oleh asam dan basa

- $\quad$ Titik pelunakan, Titik pelunakan aspal adalah antara $95-100^{\circ} \mathrm{F}$

- Kekerasan

Disebut juga penetrasi aspal.,dengan menggunakan peentrometer jarum pada suhu $25^{\circ} \mathrm{C}$. Penetrasi adalah jarak tembus suatu jarum khusus dengan beban tertentu dalam waktu 5 detik. Kekerasan aspal dinyatakan dalam suhu dan penetrasi, misalnya penetrasi pada $25^{\circ} \mathrm{C}=60$, ditulis Aspal 50/60, artinya aspal mempunyai penetrasi antara 50 - 60 satuan.

- Kemuluran

Adalah jarak dalam sentimeter, yang mana aspal yang telah dicetak dan ditarik diantara kedua ujungnya dengan kecepatan $5 \mathrm{~cm} /$ menit pada suhu 25 ${ }^{\circ} \mathrm{C}$. Aspal memiliki kemuluran dari $0-100 \mathrm{~cm}$.

Diantara sifat-sifat aspal, yang terpenting adalah titik pelunakan, kekerasan, dan kemuluran.

\subsection{Macam - Macam Aspal}


berdasarkan konsistensinya, aspal dibagi ke dalam 3 (tiga) golongan, yaitu aspal padat, aspal setengah padat, dan aspal cair.

\section{- Aspal Padat,}

Adalah aspal yang pada suhu biasa berupa zat padat. Untuk dapat digunakan dalam keadaan cair, aspal padat harus dipanaskan lebih dahulu.

\section{- Aspal Setengah Padat,}

Disebut juga aspal semen, dapat dibagi lagi berdasarkan kekerasannya dan konsistensinya.

\section{- Aspal Cair,}

Adalah aspal yang dilarutkan dalam zat pelarut, sering juga disebut cut black asphalt. Ada tiga macam aspal cair tergantung pada zat pelarut yang digunakan.

$>$ Aspal cair dengan zat pelarut Nafta, akan cepat mengeras, disebut juga rapid curing atau $R C$ asphalt.

$>$ Aspal cair dengan zat pelarut kerosin, akan lambat mengeras, disebut juga medium curing atau $\mathrm{MC}$ asphalt.

$>$ Aspal cair dengan zat pelarut minyak gas, akan sangat lambat mengeras, disebut juga slow curing atau SC asphalt.

Selain aspal cair, ada juga aspal emulsi, yang dibuat dengan cara mengemulsikan aspal dalam air dengan menggunakan emulgator.

\subsection{Penggunaan Aspal}

Aspal umumnya digunakan untuk perekat pada konstruksi pengerasan jalan. Selain itu, juga untuk: 
- Melapisi atap,

- Melapisi saluran pipa,

- Bahan pelindung,

- Kotak baterai,

- Melapisi bagian bawah mobil, dan lain - lain.

\section{KEROSIN}

Sumber: "Parafin Normal", Pengolahan Hidrokarbon 80 (2001), Randy Schueller

\subsection{Definisi Kerosin}

Minyak tanah, adalah minyak sulingan yang biasa digunakan sebagai bahan bakar atau pelarut, merupakan cairan tipis dan bening yang terdiri dari campuran jidrokarbon yang mendidih antara $150-300^{\circ} \mathrm{C}\left(302-530^{\circ} \mathrm{F}\right)$. Minyak tanah, terutama berasal dari minyak bumi.

\subsection{Proses Manufaktur}

\section{Pemulihan Minyak Mentah}

- Mengumpulkan minyak mentah,

- Pencucian minyak mentah dari kotoran, dengan menggunakan Desalting, yaitu operasi pembersihan, baik yang dilakukan di ladang minyak maupun di kilang. Setelah dicuci, airnya dipisahkan dari minyak melalui proses ekstraksi. Karena minyak mentah merupakan kombinasi dari berbagai senyawa hidrokarbon yang saling bercampur, maka harus dipisahkan menjadi komponennya sebelum diubah menjadi minyak tanah.

\section{Pemisahan}


$>$ Salah satu jenis proses pemisahan dengan melibatkan pemanasan minyak mentah untuk memisahkan komponennya, yaitu Proses Distilasi.

Aliran minyak dipompa ke dasar kolom distilasi untuk dipanaskan, kemudian komponen hidrokarbon yang lebih ringan naik ke puncak kolom dan sebagian besar fraksi titik didih tinggi tertinggal di bawah.

Di bagian atas kolom, uap yang lebih rngan ini mencapai kondensor untuk didinginkan, dan mengembalikannya ke keadaan cair. Kolom yang digunakan untuk untuk memisahkan minyak ringan secara proporsional tinggi dan tipis (tingginya 116 kaki atau $35 \mathrm{~m}$ ), karena hanya memerlukan tekanan atmosfir.

Untuk memisahkan beberapa fraksi minyak yang lebih berat, kolom distilasi harus dioperasikan kira-kira seper-sepuluh dari tekanan atmosfir $(75 \mathrm{mmHg})$. Kolom vakum ini terstruktur sangat lebar dan pendek untuk membantu mengendalikan fluktuasi tekanan, umumnya berdiameter di atas 40 kaki (12 meter).

$>5$ (lima) fraksi cair terkondensasi dapat dikumpulkan secara terpisah. Fraksi yang dikumpulkan antara $300-500^{\circ} \mathrm{F}\left(150-300^{\circ} \mathrm{C}\right)$, adalah minyak tanah.

Sebagai perbandingan, bensin disuling antara $30-150^{\circ} \mathrm{C}$, dengan mendaur ulang minyak tanah suling melalui kolom pemurnian. Proses daur ulang dikenal dengan nama refluks.

\section{Pemurnian}

Setelah minyak disuling ke dalam fraksinya, pengolahan lebih lanjut dalam serangkaian reaktor kimia, untuk mendapatkan minyak tanah. 
Dengan Pengubahan katalis, akilkasi, perengkahan katalitik, dan hidroprosesor, adalah empat teknik pemrosesan utama yang digunakan dalam konversi minyak tanah. Reaksi ini digunakan untuk mengendalikan distribusi rantai karbon dengan menambahkan atau melepaskan atom karbon dan "tulang punggung" hidrokarbon. Proses ini melibatkan pengalihan fraksi minyak mentah ke dalam bejana terpisah yang mana bahan kimia diubah menjadi minyak tanah.

Setelah minyak tanah direaksikan, ekstraksi tambahan diperlukan untuk menghilangkan kontaminan sekunder yang dapat mempengaruhi sifat pembakaran minyak.

Senaywa aromatik, yang merupakan struktur cincin karbon seperti benzene, adalah kelompok kontaminan yang harus dilepas. Sebagian besar proses ekstraksi dilakukan di menara yang besar tersebut.

\subsection{Proses Penyulingan (Pemurnian) Kerosin}

Memaksimalkan waktu kontak antara minyak tanah dan pelarut ekstraksi. Pelarut dipilih berdasarkan kelarutan kotoran, maksudnya adalah kotoran kimia lebih mudah larut dalam pelarut daripada minyak tanah.

Oleh karena itu, saat minyak mentah mengalir melalui menara, kotoran akan cenderung ditarik ke dalam fase pelarut. Setelah kontaminan dari minyak tanah, pelarut dikeluarkan (meninggalkan minyak tanah) dalam keadaan yang lebih murni.

Adapun teknik ekstraksi, yang umumnya digunakan untuk memurnikan minyak tanah,

\section{$\checkmark \quad$ Proses Ekstraksi Udex}


Menggunakan bahan kimia, yang dikenal dengan glikol sebagai pelarut. dietilena glikol dan tetraetilen glikol, digunakan karena keduanya memiliki afinitas tinggi untuk senyawa aromatik.

\section{$\checkmark \quad$ Proses Sulfolane}

Diciptakan oleh perusahaan Shell pada tahun 1962. Pelarut yang digunakan adalah Sulfolana, dan merupakan senyawa polar kuat yang lebih efisien daripada sistem glikol di atas. Proses ini menggunakan peralatan yang dikenal sebagai kontraktor disk berputar untuk membantu memurnikan minyak tanah.

\section{$\checkmark \quad$ Proses Lrosgi Lurgi}

Menggunakan $\mathrm{n}$ - metal - 2 - ryrroldinone yang dicampur dengan air atau glikol untuk meningkatkan selektivitas pelarut kontaminan. Proses ini melibatkan penggalian menara hingga diameter 20 kaki (6 meter) dan tinggi $116 \mathrm{kaki}$ meter).

\section{$\checkmark \quad$ Proses Dimetil Sulfoksida}

Melibatkan 2 (dua) tahap ekstraksi yang terpisah dengan peningkatan selektivitas kontaminan aromatik. Hal ini memungkinkan ekstraksi kontaminan ini pada suhu yang rendah. Selain itu bahan kimia yang digunakan dalam proses ini tidak beracun dan relatif murah. Menggunakan kolom khusus, yang dikenal sebagai kolom Kuhni berdiameter hingga 10 kaki (3 meter).

\section{$\checkmark \quad$ Proses Union Carbide}

Menggunakan pelarut tetraetylene glikol dan menambahkan proses ektraksi bertingkat. Ini agak lebih rumit daripada proses glikol lainnya.

\section{Proses Formex}


Menggunakan morfolin $\mathrm{n}$ - formil dan sebagian kecil air sebagai pelarut dan cukup fleksibel untuk mengekstrak aromatic dan berbagai bahan hidrokarbon.

\section{$\checkmark \quad$ Proses Redoks (Recycle Extract Dual Extraction)}

Menggunakan bahan bakar diesel untuk menghasilkan minyak tanah aromatik. Dengan ini, meningkatkan jumlah oktan bahan bakar dengan cara selektif menghilangkan kontaminan aromatic. minyak tanah aromatik yang dihasilkan melalui proses ini sangat diminati untuk memproduksi bahan bakar penerbangan dan militer lainnya.

\subsection{Pemrosesan Akhir}

Setelah proses ektraksi selesai, minyak tanah yang telah disempurnakan disimpan dalam tangki untuk pengiriman. Hal ini didistribusikan oleh truk tangki ke fasilitas yang mana minyak tanah dikemas untuk keperluan komersial.

Minyak tanah industri, disimpan dalam tangki logam besar, namun bisa dikemas dalam jumlah kecil untuk penggunaan komersial. Wadah logam dapat digunakan karena minyak tanah bukanlah gas dan tidak memerlukan bejana penyimpanan bertekanan. Namun sifat mudah terbakarnya, sehingga dianggap zat yang berbahaya.

\subsection{Kontrol Kualitas}

Proses distilasi dan ekstraksi tidak sepenuhnya efisien dan beberapa langkah pengolahan mungkin harus diulang untuk memaksimalkan produk minyak tanah.

Sebagai contoh, beberapa hidrokarbon yang tidak tertukar dengan pemisahan distilasi lebih lanjut dan didaur-ulang untuk umpan lain ke dalam konverter. Dengan mendaurulang limbah minyak bumi melalui urutan beberapa kali reaksi, kualitas produksi minyak tanah dapat dioptimalkan.

\subsection{Pengolahan Limbah}


Beberapa sisa fraksi minyak bumi yang tidak dapat dikonversi menjadi minyak tanah, dapat digunakan pada aplikasi lain, seperti minyak pelumas. Selain itu, beberapa kontaminan yang diekstraksi selama proses pemurnian dapat digunakan secara komersial. Dalam hal ini, termasuk senyawa aromatik tertentu, seperti parafin.

Spesifikasi untuk minyak tanah dan produk samping minyak lainnya ditetapkan oleh American Society for Testing and Materials (ASTM) dan American Petroleum Institute (API).

\subsection{Masa Depan Kerosin}

Masa depan minyak tanah, tergantung pada pebemuan aplikasi baru serta pengembangan metode produksi baru.

Penggunaan minyak tanah yang baru, diharapkan dapat meningkatkan permintaan militer untuk minyak tanah kelas tinggi (lebih berkualitas) untuk menggantikan sebagian besar bakarnya dengan JP - 8, yang merupakan bahan bakar berbasis minyak tanah.

Industri bahan bakar diesel, juga mengeksplorasi proses baru yang melibatkan penambahan minyak tanah ke bahan bakar diesel dengan kadar sulfur yang rendah untuk mencegah terjadinya gelling dalam cuaca dingin.

Penerbangan komersial, dapat diuntungkan dengan mengurangi resiko ledakan bahan bakar jet dengan menciptakan minyak tanah baru (berkabut rendah).

Pada Sektor perumahan, pemanasan dengan menggunakan minyak tanah baru yang dapat memberika perlindungan lebih baik dari resiko kebakaran, agar meningkatkan permintaan.

Seiring meningkatnya permintaan minyak tanah dan produk sampingnya, perlu metode baru untuk memperbaiki dan mengekstraksi minyak tanah. Salah satu metode yang dikembangkan oleh Exxon-Mobil, adalah cara murah untuk mengekstrak parafin normal dengan kemurnian tinggi pada minyak tanah. Proses ini menggunakan ammonia, yang mana sangat efisien menyerap kontaminan. Metode ini menggunakan teknologi adsorpsi fixed-bed fase uap dan menghasilkan parafin level tinggi yang kemurniannya lebih besar dari $90 \%$.

\section{B A B IV}




\section{DAFTAR PUSTAKA}

1. G. D. Hobson, "Modern Petroleum Technology". Applied Science Publishing Ltd, 1975.

2. H. S. Bell, "American Petroleum Refining". D. Van Nostrand Companyn Inc, New York, 1959.

3. Robert A. Meyers, "Handbook of Petroleum Refining Process". McGraw Hill Book Company inc, New York, 1966.

4. William I. Bland \& Robert L Davidson, "Petroleum Processing Handbook". McGraw Hill Book Company, New York, 1967.

5. W. L. Nelson, "Petroleum Refinery Engineering" McGraw Hill Book Company, New York, 1969.

6. Risdiyanto, ST, MT, "Mengenal Kilang Pengolahan Minyak Bumi (Refinery) di Indonesia". 2014.

7. Randy Schuller, "Parafin Normal", Pengolahan Hidrokarbon 80 (2001) 116.

8. Kontributor Zulfan Adil Putra, "Buku Pintar Migas Indonesia". 2014.

9. "Refining Technology", DIREKTORAT PENGOLAHAN PERTAMINA, Januari, 2015.

10. A. Hardjono, "Teknologi Minyak Bumi". Gadjah Mada University Press, 2001. 